\title{
A DELEGAÇÃO AOS LÍDERES PARTIDÁRIOS NA CÂMARA DOS DEPUTADOS E NO SENADO FEDERAL ${ }^{1}$
}

\author{
Geralda Luiza de Miranda
}

\begin{abstract}
RESUMO
Neste artigo, são comparadas as prerrogativas dos líderes para coordenarem o processo legislativo $e$ distribuírem cargos na Câmara e no Senado. A comparação é feita a partir da análise dos regimentos e resoluções que regulam a dinâmica das duas casas após 1989. Os Diários do Senado, as reportagens veiculadas pela Agência Câmara de Notícias e os estudos que tratam da dinâmica legislativa brasileira ilustram a análise e fornecem a base empírica de diversas inferências. A análise mostra a centralidade das lideranças na coordenação do processo legislativo e na distribuição dos cargos, especialmente na Câmara dos Deputados, ou seja, a importância desses atores para que os parlamentares possam superar os imperativos práticos da ação coletiva e maximizar suas preferências. Mostra também mudanças institucionais importantes que influenciam positivamente o conteúdo da delegação aos líderes. Na medida em que fortalecem as lideranças e, portanto, os partidos políticos, essas mudanças apontam para o fortalecimento do poder Legislativo vis-à-vis o poder Executivo.
\end{abstract}

PALAVRAS-CHAVE: partidos políticos; delegação legislativa; regimento interno; Câmara dos Deputados; Senado Federal.

\section{INTRODUÇÃO}

A delegação de prerrogativas e competências legislativas é uma prática recorrente em todos os sistemas políticos contemporâneos e visa, especialmente, à superação dos problemas de ação coletiva que cercam as deliberações de qualquer assembléia, principalmente aquelas de maior magnitude. Os resultados da delegação são a diminuição dos custos de transação, a estabilidade das escolhas e uma melhor coordenação da ação coletiva em torno das opções políticas preferidas pelos atores que detêm poderes de agenda e de veto ou, nos termos de Shepsle (1989), um equilíbrio institucionalmente induzido. Assim,

\footnotetext{
1 Este artigo é parte de minha tese de doutorado em Ciência Política (MIRANDA, 2008). As críticas e sugestões dos pareceristas da Revista de Sociologia e Política à primeira versão deste artigo, as de meu orientador Carlos Ranulfo e as dos professores que integraram a banca de defesa (Argelina Figueiredo, Fábio Wanderlei Reis, Jairo Nicolau e Magna Inácio) contribuíram para melhorar a discussão aqui desenvolvida. Agradeço a todos. Agradeço também as bolsas de estudo do Conselho Nacional de Desenvolvimento Científico e Tecnológico (CNPq) e da Coordenação de Aperfeiçoamento de Pessoal de Nível Superior (Capes) no período de elaboração da tese.
}

conforme ressaltam Kiewiet e McCubbins (1991), as escolhas feitas para a superação dos imperativos práticos da ação coletiva variam de acordo com os imperativos políticos que orientam as escolhas dos legisladores nos processos de (re)construção institucional. São esses imperativos políticos que definem o conteúdo e a magnitude da delegação que será feita a atores internos às assembléias, tais como comissões ou partidos, ou a atores externos, por exemplo, burocracias, tribunais e, no caso dos sistemas presidencialistas, o poder Executivo.

A Constituição brasileira, de 1988, e os regimentos e resoluções que regulam a dinâmica interna das Casas legislativas, a partir de 1989, traçam uma estrutura complexa de delegação legislativa que incorpora fortemente as lideranças partidárias e o poder Executivo. Um Executivo com fortes prerrogativas legislativas não é uma inovação da Constituição de 1988. Esta tem sido uma característica do sistema político brasileiro desde a década de 1930, independentemente do processo de elaboração constitucional. As prerrogativas ativas, isto é, as de propor legislação, de modo exclusivo ou não, e as prerrogativas reativas, que são as de reagir à legislação produzida pelo Congresso (CAREY \& SHUGART, 1998), 
estão presentes tanto nas constituições promulgadas por decreto presidencial (1937 e $1969^{2}$ ) e na que foi elaborada sob regime de exceção (1967), quanto naquelas cuja elaboração ocorreu por iniciativa de um Legislativo democraticamente eleito $(1934,1946,1988)^{3}$. A natureza path dependent dos processos de elaboração constitucional e a urgência e complexidade das decisões a serem tomadas são apresentadas pelos analistas como fatores que têm estimulado a ampla delegação (BARROS, 1975; MENDES, 1975; FIGUEIREDO \& LIMONGI, 2006; SANTOS, 2006).

No que se refere às prerrogativas das lideranças partidárias, o estudo de Gomes (2006) mostra que elas foram fortalecidas significativamente em 1988, na segunda etapa dos trabalhos da Assembléia Nacional Constituinte. Esta teria sido a estratégia encontrada pelos constituintes para acelerar as negociações entre as forças políticas naquela ocasião.

O regimento que vigorou na Câmara dos Deputados até o final de 1987 já possuía institutos de delegação às lideranças, por exemplo, a prerrogativa de indicar os membros, relatores e presidentes das comissões e subcomissões temáticas e da Comissão de Sistematização, que tinha a atribuição de consolidar o trabalho de todas as outras comissões. De acordo com Gomes, esse formato permitiu que os maiores partidos, em especial o Partido do Movimento Democrático Brasileiro (PMDB) que possuía 54\% da representação na Assembléia, fizessem as indicações de presidentes e relatores entre seus membros mais progressistas. O resultado foi um profundo desagrado por parte das forças políticas de matiz mais conservador com o Primeiro Projeto de Constituição e com o Regimento Interno, que dificultava a alteração desse projeto por meio de emendas de plenário. Formou-se, então, uma coalizão de veto, o "Centrão", que conseguiu

\footnotetext{
2 Mais especificamente, Emenda Constitucional n. 1. Por sua amplitude, essa emenda é freqüentemente entendida como uma Constituição.

3 Constituição (1934), art. 45 e 50; Constituição (1937), art. 13, 14, 64 e 65; Constituição (1946), art. 65, 67, 70 e 87; Constituição (1967), art. 50, 54, 55, 60, 62 e 67; Emenda Constitucional n. 1, 1969, art. 59; Constituição (1988), art. 61, 62, 63, 64, 66, 68 e 84 (BRASIL, 1934; 1946; 1967; $1969 ; 1988)$.
}

aprovar um novo regimento em janeiro de 1988. Apesar de facilitar alterações no Primeiro Projeto de Constituição, aquele regimento também não economizava os custos de transação. A solução encontrada foi a centralização das negociações nos líderes partidários. Nas palavras de Gomes, “[...] os líderes dos 10 maiores partidos na Assembléia Nacional Constituinte passaram a se reunir de manhã para que se alcançasse um consenso quanto ao conteúdo das propostas de modificações para que, à tarde, pudessem iniciar o processo de discussão e votação" (2006, p. 212; com adaptação).

A centralização das negociações nas lideranças não logrou dirimir todos os conflitos em torno do conteúdo da nova Carta, e muitas decisões importantes foram postergadas para a legislação infraconstitucional. No entanto, como observa Gomes, essa estratégia imprimiu maior velocidade aos trabalhos da Assembléia.

As inovações no formato da delegação às lideranças, inauguradas na Constituinte, foram assimiladas pelo Regimento Comum, que regula a dinâmica do Congresso Nacional, e pelo Regimento Interno do Senado Federal (BRASIL. Senado Federal, 1970), ambos de 1970. O Regimento Interno da Câmara dos Deputados (BRASIL. Câmara dos Deputados, 1989), aprovado em 1989, revogou o regimento que vigorava nessa Casa desde 1972 e formalizou as inovações.

$\mathrm{Na}$ prática, a forte delegação legislativa aos líderes partidários e ao poder Executivo, instituída no final da década de 1980 , centraliza o processo decisório nas mãos desses dois atores, o que tem imprimido ao processo legislativo atual uma dinâmica diferente daquela que vigorou no período democrático de 1946-1964. Na medida em que os parlamentares dependem dos recursos distribuídos por esses atores para maximizarem suas preferências em torno de políticas e de cargos, essa estrutura de delegação tem propiciado a influência do Executivo no ritmo e no conteúdo da produção legislativa. (SANTOS, 1997; 1999; 2002; FIGUEIREDO \& LIMONGI, 1999; 2002; 2006; 2007; 2008; AMORIM NETO \& SANTOS, 2003; LIMONGI \& FIGUEIREDO, 2005). Isso porque as lideranças partidárias, especialmente as dos partidos da base governista, cumprem um papel importante: o de intermediários nas negociações entre o poder Executivo e os parlamentares individualmente. 
Cabe observar que um Executivo dotado de importantes prerrogativas legislativas não significa, necessariamente, poder Legislativo com capacidade decisória diminuída. Algumas condições transformam a distribuição do poder legislativo em uma estratégia que possibilita economia significativa de recursos e melhoria na qualidade da legislação produzida, o que significa retornos positivos para a sociedade e para o próprio Legislativo.

A primeira condição para esse resultado é que a divisão do poder legislativo ocorra em contextos democráticos, ou seja, que não seja resultado de usurpação de poderes. A segunda condição é que os principals possuam capacidade organizacional e informacional para controlar as ações dos agents (LUPIA \& MCCUBBINS, 1995). Para isso, fazse necessário que as assembléias construam mecanismos que lhes permitam, por exemplo, convocar agentes públicos para prestar informações, realizar audiências públicas, instaurar comissões parlamentares de inquérito. No Brasil, de acordo com Figueiredo (2001), esses mecanismos e as condições para o fortalecimento dos tribunais de contas, um ator importante para a fiscalização dos atos da administração pública, foram consagrados na Constituição de 1988. A terceira condição está relacionada com os partidos políticos, os atores por excelência do processo legislativo. É preciso que eles tenham autonomia - daí a importância da democracia - e capacidade para colocar em funcionamento os mecanismos de controle do agenciamento disponíveis e aplicar as sanções eventualmente necessárias.

Mas partidos políticos são, como as próprias assembléias, atores coletivos e, enquanto tais, reféns de inúmeros problemas de ação coletiva. Sua capacidade para colocar em funcionamento os mecanismos informacionais e de controle do agenciamento está estreitamente relacionada com a capacidade das lideranças para coordenar a atuação de suas bancadas no processo legislativo. Nesse ponto, os recursos que elas possuem para premiar e punir o comportamento dos parlamentares, independentemente daqueles monopolizados pelo poder Executivo, adquirem importância crucial.

O objetivo deste artigo é comparar a delegação de prerrogativas às lideranças partidárias na Câmara dos Deputados e no Senado Federal. Essa comparação é feita a partir da análise detalhada dos regimentos e resoluções que regulam a dinâmica do processo legislativo. Considerando que a importância das prerrogativas dos líderes depende do poder que os parlamentares mantêm individualmente e daquele que é delegado a outros atores, a comparação toma a forma de uma avaliação geral da delegação instituída nas duas Casas ${ }^{4}$. Os achados de estudos relativos à dinâmica interna dos órgãos legislativos e à relação entre os poderes Executivo e Legislativo, no Brasil, ilustram a comparação. Além desses estudos, os Diários do Senado Federal e as reportagens da Agência Câmara de Notícias fornecem a base empírica de algumas inferências sobre os efeitos das regras regimentais das duas Casas legislativas.

A literatura que trata da delegação legislativa salienta a importância das prerrogativas que permitem às lideranças maximizarem as preferências dos parlamentares em torno de cargos e de políticas (KIEWIET \& MCCUBBINS, 1991; COX \& MCCUBBINS, 1993; 1995; SINCLAIR, 1995; FIGUEIREDO \& LIMONGI, 1999; CAREY, 2006). Adotando essa mesma distinção, comparo, na segunda seção, as prerrogativas dos líderes partidários para constituir os cargos internos da Câmara dos Deputados e do Senado Federal. Na terceira seção, são comparadas as prerrogativas que permitem a eles coordenarem a dinâmica do processo legislativo nas duas Casas.

$\mathrm{Na}$ análise, constato a centralidade dos líderes partidários na coordenação do processo legislativo e na distribuição dos cargos, especialmente na Câmara dos Deputados, ou seja, sua importância para a superação dos imperativos práticos da ação coletiva legislativa. Constato também mudanças institucionais importantes que influenciam positivamente o conteúdo da delegação aos líderes, mais especificamente, a vinculação do critério da proporcionalidade partidária aos resultados das

\footnotetext{
4 Nas deliberações do Congresso Nacional, vigoram as mesmas regras que organizam as sessões separadas da Câmara e do Senado. Essas regras estão relacionadas com o tipo de proposição e não propriamente com a Casa legislativa em que é deliberada. Além disso, e mais importante para o objetivo da discussão aqui desenvolvida, os líderes que coordenam o processo legislativo nas sessões deliberativas da Câmara e do Senado, separadamente, são os mesmos que coordenam as sessões conjuntas do Congresso e indicam os nomes para o preenchimento dos cargos nas comissões mistas.
} 
urnas e a decisão do Tribunal Superior Eleitoral (TSE) de que o mandato é do partido e não do parlamentar. Considerando que essas mudanças fortalecem a capacidade dos partidos políticos para atuarem de modo independente das preferências do poder Executivo, argumento, nas conclusões, que elas apontam para uma alteração importante nos imperativos políticos que orientaram a delegação legislativa no final da década de 1980.

\section{II.AS PRERROGATIVAS DAS LIDERANÇAS PARLAMENTARES NADISTRIBUIÇÃO DE CARGOS NA CÂMARA DOS DEPUTADOS E NO SENADO FEDERAL}

A constituição dos órgãos internos da Câmara dos Deputados e do Senado Federal é feita em duas etapas: a primeira envolve a divisão dos cargos entre os partidos; a segunda, a distribuição dos cargos entre os membros de cada partido. $\mathrm{O}$ critério de divisão dos cargos entre os partidos é o da proporcionalidade partidária e encontra-se constitucionalmente garantido; a distribuição dos cargos entre os membros de cada partido é atribuição regimental das lideranças, mas os critérios não estão, na grande maioria dos casos, formalmente previstos.

O critério da proporcionalidade partidária, quando utilizado para a constituição das comissões, é visto por Strom (1990) como o mais favorável à influência política dos partidos em geral e, em especial, a daqueles que estão na oposição ao governo. No Brasil, quando da distribuição dos cargos entre os partidos, concilia-se a regra da proporcionalidade com os acordos de lideranças, o que pode resultar na formação de um "cartel legislativo" favorável aos interesses do governo (AMORIM NETO, COX \& MCCUBBINS, 2003; SANTOS \& ALMEIDA, 2005; INÁCIO, 2006), se os maiores partidos integrarem sua base de apoio. Entre os cargos mais importantes, adquirem relevo a presidência da Mesa Diretora da Câmara dos Deputados e do Senado Federal e a das comissões hierarquicamente mais valorizadas, tais como, a Comissão de Constituição, Justiça e Cidadania das duas Casas, a Comissão de Assuntos Econômicos do Senado, a Comissão de Fiscalização e Controle da Câmara e, por fim, a Comissão Mista de Planos, Orçamentos Públicos e Fiscalização do Congresso Nacional (doravante Comissão Mista de Orçamento) (FIGUEIREDO \& LIMONGI, 1999; 2002; PEREIRA \& MUELLER, 2000; 2002; 2006; PEREIRA \&
RENNÓ, 2001; SANTOS, 2002; LIMONGI \& FIGUEIREDO, 2005; LEMOS, 2006).

Estudos sobre a constituição das comissões mostram que a regra da proporcionalidade e os acordos entre as lideranças vigoram efetivamente na distribuição das presidências nas duas Casas legislativas. Esses acordos têm início, frequentemente, com a formação de blocos de partidos antes da distribuição dos cargos, o que permite a repartição das presidências das comissões mais valorizadas entre os partidos do bloco majoritário. De qualquer forma, a regra da proporcionalidade é o critério principal, como mostram Santos e Almeida (2005) quando verificam a relação entre o tamanho dos partidos e a distribuição de presidências na Câmara no primeiro governo de Fernando Henrique Cardoso. No caso do Senado, a análise de Lemos (2006) mostra que os partidos de oposição ocuparam, entre 1991 e 2000, apenas a presidência de comissões menos valorizadas (Comissão de Assuntos Sociais e Comissão de Infra-estrutura).

Para a distribuição dos cargos entre os partidos na Câmara, prevê-se, de modo subsidiário à regra da proporcionalidade, a experiência, o direito das minorias e a auto-indicação. $O$ direito das minorias é assegurado na distribuição dos cargos da Mesa e das comissões, mesmo que elas não tenham acesso a esses cargos pela regra da proporcionalidade. A auto-indicação está prevista para o cargo de presidente da Mesa e pode ser feita pelos membros do partido majoritário. A experiência deve estar combinada com a proporcionalidade na distribuição dos cargos do Conselho de Altos Estudos e Avaliação Tecnológica, um órgão que existe apenas nessa Casa.

Dada a significativa oscilação no tamanho das bancadas partidárias, resultante da migração partidária entre as eleições (SANTOS, 2001; MELO, 2003; 2004; MELO \& MIRANDA, 2006), cabe questionar a eficácia do critério da proporcionalidade em permitir a influência dos partidos políticos no processo legislativo brasileiro, nos termos colocados por Strom (1990). Se os partidos assistem impotentes à diminuição do tamanho de suas bancadas, como afirmar que eles possuem capacidade de coordenar a ação coletiva na arena legislativa? Nesse aspecto, faz-se necessário, no entanto, considerar duas mudanças institucionais recentes que favorecem o 
fortalecimento do critério da proporcionalidade e, consequentemente, reforçam o poder dos partidos na coordenação do processo legislativo e na distribuição de direitos parlamentares.

Nos regimentos da Câmara e do Senado, previa-se, até 2007, que a mudança de partido pelo parlamentar implicava perda do cargo que ele ocupasse em razão da proporcionalidade, exceto se os cargos fossem na Mesa Diretora. A mudança não trazia, no entanto, maiores prejuízos, pois bastava ao migrante esperar uma nova distribuição das vagas entre os partidos, o que era feito no início de cada sessão legislativa. Aumentada a proporcionalidade dos partidos que atraíram mais parlamentares, que no início da legislatura tem sido, em sua maioria, os partidos da coalizão governista (MELO, 2003; 2004), o migrante tinha novamente a possibilidade de integrar as comissões mais valorizadas.

Na Câmara, em 2007, esse quadro alterou-se com a entrada em vigor da Resolução 34, aprovada em 2005. Essa resolução estipula apenas uma distribuição da quota dos partidos nas comissões, no início da legislatura, e a perda de cargos em virtude de migrações, inclusive os da Mesa Diretora (BRASIL. CÂMARA DOS DEPUTADOS, 1989, art. $8^{\circ}$ ). No Senado, mudança na mesma direção foi assegurada pela Resolução 35, aprovada em 2006, que institui que a proporcionalidade verificada no ato da diplomação vale para toda a legislatura. Essa resolução passou a vigorar também em 2007.

A segunda alteração diz respeito à decisão do TSE, em 2007, de que a posse do mandato é do partido e não do parlamentar. Essa decisão possibilita às lideranças parlamentares a reivindicação da "cadeira" deixada livre pelo migrante e, assim, torna a regra da proporcionalidade, tal como surgida das urnas, potencialmente mais efetiva ${ }^{5}$. Ao tornar crível a ameaça de perda de mandato, um recurso importante para os partidos, a iniciativa certamente contribui para seu fortalecimento. Cabe ressaltar que a decisão não foi contestada pelos maiores partidos. Ao contrário, ela foi apoiada por aqueles que estavam na oposição e pelos que integravam formalmente a base governista 6 .

Os Quadros 1 e 2 fornecem um panorama dos cargos-órgãos, previstos nos regimentos das duas Casas e em resoluções relacionadas, que são ocupados exclusiva ou majoritariamente por parlamentares. Distinguem-se a modalidade de seleção dos candidatos/ocupantes de cada cargo (indicação das lideranças, indicação e eleição pelos membros, designação pelo presidente), de quem é a prerrogativa da seleção (maioria do plenário ou da comissão, presidente da Mesa ou de comissão, líder, Presidente da República), a periodicidade de renovação, a denominação e o número de cargos.

QUADRO 1 - PRERROGATIVAS DOS ATORES LEGISLATIVOS PARA COMPOSIÇÃO DOS CARGOS-ÓRGÃOS DACÂMARADOS DEPUTADOS

\begin{tabular}{|c|c|c|c|c|c|}
\hline CARGO/ÓRGÃO & $\begin{array}{l}\text { FORMA DE } \\
\text { SELEÇÃO }\end{array}$ & PRERROGATIVA & PERIODICIDADE & \multicolumn{2}{|c|}{$\begin{array}{c}\text { DENOMINAÇÃO E } \\
\text { QUANTIDADE DE CARGOS }\end{array}$} \\
\hline $\begin{array}{l}\text { Colégio de Líderes } \\
\text { (art. 20) }\end{array}$ & - & - & - & $\begin{array}{l}\text { Líderes de } \\
\text { partido e de bloco }\end{array}$ & Variável \\
\hline $\begin{array}{l}\text { Liderança de partido } \\
\text { e bloco (art. } 9^{\circ}, 12 \text {, } \\
\text { 13) }\end{array}$ & Indicação & Maioria da bancada & $\begin{array}{l}\text { Indicados no } \\
\text { início da } \\
\text { legislatura }\end{array}$ & Líder & Variável \\
\hline $\begin{array}{l}\text { Presidência de } \\
\text { comissão } \\
\text { permanente e } \\
\text { temporária (art. } 7^{\circ} \text {, } \\
\text { 39) }\end{array}$ & Eleição & $\begin{array}{l}\text { Maioria dos membros } \\
\text { titulares }\end{array}$ & $\begin{array}{l}\text { Anual, vedada a } \\
\text { recondução }\end{array}$ & $\begin{array}{c}\text { Presidente } \\
\text { Vice-Presidente }\end{array}$ & $\begin{array}{l}1 \\
3\end{array}$ \\
\hline
\end{tabular}

5 A decisão do TSE foi formalizada pela Resolução n. $22610 / 07$. Os eleitos para os cargos proporcionais, que 


\begin{tabular}{|c|c|c|c|c|c|}
\hline $\begin{array}{l}\text { Mesa Diretora (art. } \\
8^{\circ} \text { ) }\end{array}$ & $\begin{array}{l}\text { Eleição (entre } \\
\text { os indicados) }\end{array}$ & $\begin{array}{l}\text { Maioria dos deputados } \\
\text { Líder, bancada ou } \\
\text { deputado } \\
\text { individualmente na } \\
\text { indicação }\end{array}$ & $\begin{array}{l}\text { Bianual, vedada } \\
\text { a recondução }\end{array}$ & $\begin{array}{l}\text { Presidente } \\
\text { Vice-Presidente } \\
\text { Secretário } \\
\text { Suplente }\end{array}$ & $\begin{array}{l}1 \\
2 \\
4 \\
4\end{array}$ \\
\hline $\begin{array}{l}\text { Conselho de Altos } \\
\text { Estudos e Avaliação } \\
\text { Tecnológica (art. } \\
\text { 275) }\end{array}$ & Indicação & $\begin{array}{c}\text { Presidente da Câmara } \\
\text { Líder }\end{array}$ & Quatro anos & $\begin{array}{c}\text { Repres. }^{(1)} \text { natos } \\
\text {-da Mesa } \\
\text {-dos deputados }\end{array}$ & $\begin{array}{l}1 \\
5\end{array}$ \\
\hline $\begin{array}{l}\text { Corregedoria (art. } \\
267 \text { ) }\end{array}$ & $\begin{array}{c}\text { Designação } \\
\text { (entre os } \\
\text { membros Mesa) }\end{array}$ & Mesa & Bianual & $\begin{array}{l}\text { Corregedor }^{(2)} \\
\text { Corregedor- } \\
\text { Substituto }\end{array}$ & $\begin{array}{l}1 \\
3\end{array}$ \\
\hline $\begin{array}{l}\text { Procuradoria } \\
\text { Parlamentar (art. 21) }\end{array}$ & Indicação & Presidente da Câmara & Bianual & Membros & 11 \\
\hline $\begin{array}{l}\text { Liderança e vice- } \\
\text { liderança do governo } \\
\text { (art. 11) }\end{array}$ & Indicação & $\begin{array}{l}\text { Presidente da } \\
\text { República }\end{array}$ & - & $\begin{array}{c}\text { Líder } \\
\text { Vice-Líderes }\end{array}$ & $\begin{array}{l}1 \\
5\end{array}$ \\
\hline Relatoria (art. 41) & Designação & $\begin{array}{l}\text { Presidente de } \\
\text { comissão }\end{array}$ & Por projeto & Relator & Variável \\
\hline $\begin{array}{l}\text { Comissão } \\
\text { permanente (art. 10, } \\
\text { 28) }\end{array}$ & Indicação & Líder & Bianual & Titular & $542^{(3)}$ \\
\hline $\begin{array}{l}\text { Comissão temporária } \\
\text { (especial, externa, } \\
\text { parlamentar de } \\
\text { inquérito) (art. } 34 \text {, } \\
35,38,45 \text { ) }\end{array}$ & Indicação & Líder & $\begin{array}{l}\text { Quando } \\
\text { constituída }\end{array}$ & Titular & Variável \\
\hline $\begin{array}{l}\text { Vice-liderança de } \\
\text { partido ou bloco (art. } \\
\left.9^{\circ}\right)\end{array}$ & Indicação & Líder & A mesma do líder & $\begin{array}{c}1 \text { para } 4 \\
\text { deputados }\end{array}$ & Variável \\
\hline $\begin{array}{l}\text { Ouvidoria } \\
\text { Parlamentar (art. 21- } \\
\text { A) }\end{array}$ & Indicação & Líder & Bianual & $\begin{array}{l}\text { Ouvidor-Geral } \\
\text { Ouv. Substitutos }\end{array}$ & $\begin{array}{l}1 \\
2\end{array}$ \\
\hline $\begin{array}{l}\text { Conselho de Ética } \\
\text { (art. } 1^{\circ} \text {, parágrafo } \\
28 \text { ) }\end{array}$ & Indicação & Líder & Bianual & $\begin{array}{l}\text { Corregedor } \\
\text { Titulares/ } \\
\text { Suplentes }\end{array}$ & $\begin{array}{c}1 \\
14\end{array}$ \\
\hline
\end{tabular}

FONTE: BRASIL. Câmara dos Deputados (1989).

NOTAS: (1) Abreviatura de "representante"; (2) Corregedor-Geral da Câmara, que é membro da Mesa; (3) Total de cargos nas comissões em 2007.

mudaram de partido a partir de 27 de março de 2007 , e os eleitos para os cargos majoritários, que mudaram a partir de 16 de outubro de 2007, ficaram sujeitos à perda do mandato. Em 30 de novembro de 2007, Democratas (DEM), Partido Popular Socialista (PPS), Partido Trabalhista Cristão (PTC) e Partido dos Trabalhadores (PT) pediram de volta o mandato de seis deputados e de um senador (AGÊNCIA CÂMARA DE NOTÍCIAS, 2007).
6 A decisão foi contestada em uma Ação Direta de Inconstitucionalidade (Adin), de autoria da ProcuradoriaGeral da República e do Partido Social Cristão (PSC). Em 12 de novembro de 2008, o Supremo Tribunal Federal (STF) ratificou a decisão do TSE. Em seu voto contrário à aceitação da Adin, o Ministro Ayres Britto salientou: "A urna tem voz, e essa voz há de ecoar pelo menos por quatro anos. Não cabe ao candidato eleito, com a tesoura da infidelidade, podar esse tempo" (RESOLUÇÃO DO TSE SOBRE FIDELIDADE PARTIDÁRIA, 2008). 
QUADRO 2-PRERROGATIVAS DOS ATORES LEGISLATIVOS PARA COMPOSIÇÃO DOS CARGOS-ÓRGÃOS DO SENADO FEDERAL

\begin{tabular}{|c|c|c|c|c|c|}
\hline CARGO/ÓRGÃO & $\begin{array}{l}\text { FORMA DE } \\
\text { SELEÇÃO }\end{array}$ & PRERROGATIVA & PERIODICIDADE & \multicolumn{2}{|c|}{$\begin{array}{c}\text { DENOMINAÇÃO E } \\
\text { QUANTIDADE DE CARGOS }\end{array}$} \\
\hline $\begin{array}{l}\text { Liderança de partido } \\
\text { (art. 65) }\end{array}$ & Indicação & Maioria da bancada & Bianual & Líder & Variável \\
\hline $\begin{array}{l}\text { Presidência } \\
\text { comissão } \\
\text { permanente }^{(1)} \text { (art. } \\
88)\end{array}$ & $\begin{array}{l}\text { Eleição } \\
\text { (rotatividade } \\
\text { entre os } \\
\text { partidos) }\end{array}$ & $\begin{array}{c}\text { Maioria dos membros } \\
\text { titulares }\end{array}$ & $\begin{array}{l}\text { Bianual, vedada a } \\
\text { recondução }\end{array}$ & $\begin{array}{c}\text { Presidente } \\
\text { Vice-Presidente }\end{array}$ & $\begin{array}{l}1 \\
1\end{array}$ \\
\hline $\begin{array}{l}\text { Mesa Diretora (art. } \\
60 \text { ) }\end{array}$ & Eleição & $\begin{array}{l}\text { Maioria dos senadores } \\
\text { Não-explicitada a } \\
\text { indicação }\end{array}$ & $\begin{array}{l}\text { Bianual, vedada a } \\
\text { recondução }\end{array}$ & $\begin{array}{l}\text { Presidente } \\
\text { Vice-Presidente } \\
\text { Secretários } \\
\text { Suplentes }\end{array}$ & $\begin{array}{l}1 \\
2 \\
4 \\
4\end{array}$ \\
\hline $\begin{array}{l}\text { Conselho de Ética } \\
\text { (Resolução n. 20/93 } \\
\text { do Senado Federal) }\end{array}$ & $\begin{array}{l}\text { Indicação } \\
\text { Eleição }\end{array}$ & $\begin{array}{l}\text { Líder } \\
\text { Maioria dos senadores }\end{array}$ & Bianual & $\begin{array}{l}\text { Presidente } \\
\text { Titulares } \\
\text { Suplentes }\end{array}$ & $\begin{array}{c}1 \\
14 \\
15\end{array}$ \\
\hline $\begin{array}{l}\text { Corregedoria } \\
\text { (Resolução n. 17/93 } \\
\text { do Senado Federal) }\end{array}$ & Eleição & $\begin{array}{c}\text { A mesma dos cargos } \\
\text { da Mesa }\end{array}$ & - & $\begin{array}{l}\text { Corregedor } \\
\text { Corregedor- } \\
\text { Substituto }\end{array}$ & $\begin{array}{l}1 \\
3\end{array}$ \\
\hline $\begin{array}{l}\text { Procuradoria } \\
\text { Parlamentar } \\
\text { (Resolução n. 40/95 } \\
\text { do Senado Federal) }\end{array}$ & Indicação & Presidente do Senado & Bianual & - & 5 \\
\hline $\begin{array}{l}\text { Liderança do } \\
\text { governo (art. 65) }\end{array}$ & $\begin{array}{c}\text { Indicação (entre } \\
\text { os lideres da } \\
\text { base) }\end{array}$ & $\begin{array}{l}\text { Presidente da } \\
\text { República }\end{array}$ & - & Líder & 1 \\
\hline $\begin{array}{l}\text { Relatoria (art. 89, } \\
\text { 126) }\end{array}$ & $\begin{array}{l}\text { Designação } \\
\text { (rotatividade } \\
\text { entre partidos } \\
\text { majoritários) }\end{array}$ & $\begin{array}{l}\text { Presidente de } \\
\text { comissão }\end{array}$ & Por projeto & Relator & Variável \\
\hline $\begin{array}{l}\text { Vice-liderança do } \\
\text { governo (art. 66) }\end{array}$ & $\begin{array}{c}\text { Indicação (entre } \\
\text { os líderes da } \\
\text { base) }\end{array}$ & Líder do governo & - & Vice-líder & Variável \\
\hline $\begin{array}{l}\text { Vice-liderança } \\
\text { partido ou bloco (art. } \\
62,65)\end{array}$ & $\begin{array}{c}\text { Indicação (entre } \\
\text { os líderes) }\end{array}$ & $\begin{array}{l}\text { Líderes dos partidos } \\
\text { integrantes }\end{array}$ & $\begin{array}{l}\text { A mesma dos } \\
\text { líderes }\end{array}$ & Vice-Líder & Variável \\
\hline $\begin{array}{l}\text { Liderança de bloco } \\
\text { parlamentar, da } \\
\text { Maioria e da Minoria } \\
(\text { art. } 62,65)\end{array}$ & $\begin{array}{l}\text { Indicação (entre } \\
\text { os líderes) }\end{array}$ & $\begin{array}{c}\text { Líderes dos partidos } \\
\text { integrantes }\end{array}$ & $\begin{array}{l}\text { A mesma dos } \\
\text { líderes }\end{array}$ & Líder & Variável \\
\hline $\begin{array}{l}\text { Comissão } \\
\text { permanente (art. 78) }\end{array}$ & Indicação & Líder & Bianual & $\begin{array}{c}\text { Titular } \\
\text { Suplentes }\end{array}$ & $\begin{array}{l}210^{(2)} \\
\text { idem }\end{array}$ \\
\hline
\end{tabular}

FONTE: BRASIL. Senado Federal (1970; 1993a; 1993b; 1995).

Notas: (1) Não há referência, no Regimento Interno do Senado, sobre a forma de seleção dos presidentes das comissões temporárias; (2) Consideram-se aqui 10 comissões: excluiu-se a Comissão de Ciência, Tecnologia, Inovação, Comunicação e Informática, criada pela Resolução n. 1 do Senado Federal, apenas em 2007, e constituída por 17 titulares. 
Na comparação dos órgãos/cargos existentes na Câmara e no Senado, destacam-se algumas diferenças. A primeira diz respeito ao Colégio de Líderes, que tem existência formal apenas na Câmara. Esse colegiado é constituído pelas lideranças de partidos, de blocos de partidos, da maioria e da minoria e do governo e funciona como instância de resolução de conflitos interpartidários e de consulta do presidente da Mesa Diretora. Suas decisões são tomadas pela regra majoritária, sendo os votos dos líderes de partido e de bloco ponderados pelo tamanho das respectivas bancadas. Os líderes do governo, da maioria e da minoria têm direito de participar das reuniões, mas não de votar. A segunda diferença está relacionada com o Conselho de Altos Estudos, que existe também apenas na Câmara. Esse conselho é um órgão de assessoria especializada, que conta com a participação de membros não-natos, normalmente especialistas convidados para realização de tarefas temporárias. A terceira diferença é na constituição da Ouvidoria: na Câmara, esse órgão conta com parlamentares nos cargos de Ouvidor-Geral e Ouvidores-Substitutos, o que não ocorre, pelo menos formalmente, na Ouvidoria do Senado (“Alô Senado"). Por fim, há diferenças importantes na estrutura do sistema de comissões, na participação dos parlamentares nesse sistema e na posição que ele ocupa no processo legislativo das duas Casas. Vejamos.

O sistema de comissões do Senado é constituído por 11 comissões permanentes ${ }^{7}$ e o da Câmara por praticamente o dobro: 20 comissões. O número de comissões temporárias (especial, externa ou parlamentar de inquérito) varia entre as Casas e ao longo do tempo. Nas duas Casas, a Comissão de Constituição, Justiça e Cidadania tem a atribuição de apreciar a juridicidade, legalidade e constitucionalidade das proposições, enquanto seus aspectos orçamentários e financeiros são apreciados, no Senado, pela Comissão de Assuntos Econômicos e, na Câmara, pela Comissão de Finanças e Tributação. A fiscalização da administração pública fica a cargo da Comissão de Meio Ambiente, Defesa do Consumidor e Fiscalização e Controle

\footnotetext{
7 Conforme o Regimento Interno do Senado, a Resolução n. 1, de 2005, e a Resolução n. 1, de 2007 (BRASIL. Senado Federal, 2005; 2007a). O Regimento Interno da Câmara está atualizado.
}

no Senado; na Câmara, essa função é da Comissão de Fiscalização e Controle. As outras comissões possuem atribuições temáticas nas duas Casas.

A titularidade da participação em comissões pode ser acumulada nas duas Casas, mas ela não pode ser somada com a titularidade em outros órgãos como, por exemplo, Procuradoria, Ouvidoria. Os deputados podem acumular a titularidade na Comissão de Legislação Participativa ou na Comissão de Segurança Pública e Combate ao Crime Organizado com mais duas titularidades: a primeira em outra comissão permanente e a segunda em uma comissão temporária. Podem integrar, como titulares, portanto, até três comissões, e o mesmo número como suplentes. Os senadores, até fevereiro de 2005 , podiam acumular três titularidades em comissão permanente, sendo uma delas na Comissão de Meio Ambiente, Defesa do Consumidor e Fiscalização e Controle ou na Comissão de Legislação Participativa, com uma quarta em comissões temporárias. Com a Resolução n. 1, de 2005, o número de titularidades fixas dos senadores passa para quatro, permanecendo a mesma possibilidade de acúmulo. A regra de não-cumulatividade incluía, até 2007, nas duas Casas, também os cargos da Mesa Diretora. Com a Resolução n. 3, de 2007, os senadores integrantes desse órgão, exceto o presidente, passaram a poder ocupar também outros cargos (BRASIL. SENADO FEDERAL, 2007b).

A cadeia de delegação para a constituição dos cargos/órgãos internos possui complexidade similar nas duas Casas e, em ambas, as lideranças partidárias encontram-se em posição privilegiada: são os elos centrais. Na Câmara, elas devem ser escolhidas pela maioria das bancadas no início da legislatura; no Senado, no início da primeira e terceira sessões legislativas ${ }^{8}$. Podem ser substituídas, nas duas Casas, a qualquer tempo. O "a qualquer tempo" na Câmara tem sido o início

\footnotetext{
8 Na Câmara, tem direito de escolher líder a bancada com $1 / 100$ da representação (seis deputados). No caso de bloco, a exigência aumenta para 6/100 (36 deputados). No Senado, para que a liderança possua as prerrogativas administrativas previstas, a exigência para a escolha de líder de partido é de $1 / 27$ da representação (três senadores); para líder de bloco, a exigência é de 1/10 (oito senadores). Pela leitura dos Diários do Senado, percebe-se, no entanto, que até mesmo nos partidos menores (com um ou dois membros), há um parlamentar sendo denominado líder.
} 
de cada sessão legislativa (AGÊNCIA CÂMARA DE NOTÍCIAS, 2008). Definidas as lideranças, cabe a elas indicar os nomes para os outros cargos ou participar das indicações, se a prerrogativa for de outros atores. $O$ único ator externo na cadeia de delegação é o Presidente da República, que indica o líder do governo nas duas Casas e seus vice-líderes na Câmara.

A maioria dos membros das duas Casas tem a prerrogativa de eleger os integrantes da Mesa Diretora e, no Senado, os membros do Conselho de Ética e da Corregedoria. No caso da Mesa, a eleição é feita, no Senado, entre os indicados pelas lideranças e, na Câmara, entre estes e os que eventualmente se auto-indicam. A eleição dos presidentes de comissão é prerrogativa de seus titulares e não está prevista, nos dois regimentos, a indicação prévia dos nomes por parte das lideranças. No entanto, na prática, há participação ativa das lideranças nessa seleção especialmente quando se trata de comissões com centralidade no processo legislativo (idem).

Para a constituição dos outros cargos-órgãos, os membros das duas Casas delegam poderes a outros atores. Os integrantes da Corregedoria compõem a Mesa nas duas Casas, mas, no Senado, eles devem também ser eleitos pelo plenário. Procedimento similar ocorre na constituição do Conselho de Ética: indicação pelos líderes e, no Senado, eleição pelo plenário. A Mesa também tem a prerrogativa de indicar os membros da Procuradoria nas duas Casas e, na Câmara, é prerrogativa sua e das lideranças a escolha dos membros natos do Conselho de Altos Estudos.

Os presidentes de comissão têm a prerrogativa de escolher os relatores nas duas Casas. No regimento do Senado, exige-se que essa escolha obedeça à proporcionalidade partidária, mas que seja feita também rotatividade entre os partidos majoritários. No regimento da Câmara, não se prevê nenhum critério para essa indicação.

$\mathrm{Na}$ prática, durante o primeiro governo de Fernando Henrique Cardoso, de acordo com Santos e Almeida (2005), foram considerados, especificamente na indicação para as relatorias de proposições encaminhadas pelo poder Executivo, o pertencimento do parlamentar à coalizão governista, caso o presidente da comissão também integrasse essa base, e sua experiência. Essa estratégia leva os autores a concluírem que a atenção aos critérios partidários não se faz em detrimento da especialização, o que permite que os relatores funcionem como "agentes informacionais" da comissão. Analisando a mesma legislatura, Pereira e Mueller (2000) também chegam a conclusões semelhantes. Müller (2005), por outro lado, também tratando da mesma legislatura, indica a relevância de critérios relacionados com a trajetória do deputado (lealdade política, filiação partidária, ocupação de cargos partidários), o que não chega a contradizer as outras análises. Assim, também na segunda etapa de constituição dos órgãos decisórios - distribuição dos cargos entre os membros do partido - parece haver prevalência de critérios que favorecem a influência dos partidos no processo decisório.

Nas duas Casas, as lideranças possuem ainda a prerrogativa de escolher seus vice-líderes e os titulares e suplentes que integram as comissões permanentes e temporárias e as comissões mistas, também permanentes e temporárias, do Congresso Nacional. A importância dessa prerrogativa não deriva propriamente da indicação, posto que os parlamentares têm direito de integrar as comissões nas duas Casas, mesmo que não estejam filiados a partidos, mas sim da hierarquia do sistema de comissões. Integrar a Comissão de Constituição e Justiça, a Comissão de Assuntos Econômicos e a Comissão de Finanças e Tributação, que têm o poder de "engavetar" as proposições", a Comissão Mista de Orçamento, que possibilita certo controle do acesso a recursos orçamentários, ou mesmo uma comissão temporária, como as parlamentares de inquérito, permite maior visibilidade política ou maior probabilidade de influenciar o processo legislativo do que integrar as comissões temáticas, embora estas também possam ser de crucial importância para que os parlamentares maximizem suas preferências em torno de políticas. De qualquer forma, na literatura posterior ao trabalho de Figueiredo e Limongi (1999), a prerrogativa de indicar os nomes que integram as comissões é entendida como um dos principais poderes delegados às lideranças partidárias.

A partir dos dados apresentados, pode-se inferir que esse poder é maior na Câmara dos Deputados do que no Senado Federal. Considerando apenas o número de titularidades nas comissões

\footnotetext{
9 Esse poder deriva do fato de que o parecer emitido por essas comissões é "terminativo", ou seja, só pode ser contestado pelos parlamentares mediante recurso ao plenário.
} 
permanentes das duas Casas e do Congresso Nacional ${ }^{10}$, ficam à disposição de cada deputado e de cada senador, que não integre os cargos nãoacumuláveis, 1,3 e 4,8 cargos respectivamente ${ }^{11}$. Assim, para a maximização dos interesses em torno de cargos, a dependência de um parlamentar comum - aquele que não tem perfil para ocupar as posições de maior destaque - da boa vontade de seu líder é quase três vezes maior na Câmara do que no Senado.

Na próxima seção, serão avaliadas as condições para a maximização do interesse dos parlamentares em torno de políticas, estabelecidas pelos regimentos e resoluções das duas Casas legislativas.

\section{AS PRERROGATIVAS DAS LIDERANÇAS PARTIDÁRIAS NO PROCESSO LEGIS- LATIVO DA CÂMARA DOS DEPUTADOS E DO SENADO FEDERAL}

$\mathrm{O}$ ator legislativo mais poderoso na Câmara e no Senado, depois do plenário, é o presidente da Mesa Diretora. Entre suas atribuições, destacamse as seguintes: definir a agenda mensal, determinar a "ordem do dia", presidir as sessões, distribuir matérias às comissões, declarar prejudicialidade de proposição ${ }^{12}$, nomear relator em plenário, desempatar votações, interpretar o regimento. Os presidentes ainda reúnem, junto com os outros integrantes da Mesa, as prerrogativas disciplinares, administrativas, financeiras e orçamentárias das respectivas Casas.

$\mathrm{Na}$ definição da agenda, os presidentes contam com a participação das lideranças nas duas Casas. No Senado, os critérios de escolha das proposições são a sua importância e antiguidade ${ }^{13}$. A antiguidade só pode ser desconsiderada para a inclusão de até três proposições e deve haver consenso sobre elas. $\mathrm{Na}$ Câmara, o Colégio de Líderes é ouvido na composição da agenda, mas não há critérios regimentalmente definidos para a escolha das proposições.

Tendo contribuído para a definição da pauta de votações, os líderes colocam-se, nas duas Casas, como intermediários entre os parlamentares e a Mesa ou o plenário quando eles buscam alterar a pauta da "ordem do dia" e o processo de discussão e votação das proposições. Os Quadros 3 e 4 mostram as prerrogativas legislativas dos diversos atores, nesses procedimentos, na Câmara dos Deputados e no Senado Federal.

\footnotetext{
10 São duas as comissões permanentes do Congresso: Comissão Representativa do Mercosul e Comissão Mista de Orçamento. A primeira é constituída por oito deputados e oito senadores; a segunda era constituída por 63 deputados e 21 senadores (BRASIL. CONGRESSO NACIONAL, 1995). A partir da Resolução n. 1, de 2006, do Congresso Nacional, a Comissão Mista de Orçamento passa ser formada por 40 deputados e 10 senadores. Comissão Representativa do Congresso Nacional é constituída por 16 deputados e sete senadores, mas os membros da Mesa também a integram e ela é formada apenas nos recessos parlamentares (BRASIL. CONGRESSO NACIONAL, 2000).

11 Do cálculo para a Câmara foi retirada a soma das titularidades dos cargos da Mesa, Conselho de Altos Estudos, Procuradoria, Ouvidoria e Conselho de Ética; para o Senado, foi retirada a soma dos cargos da Mesa, Procuradoria, Conselho de Ética e Corregedoria. A alteração na constituição da Comissão Mista de Orçamento não foi considerada.

12 O presidente da Mesa pode declarar que a proposição está prejudicada na Câmara (art. 164) e no Senado (art.

334) por ela "ter perdido a oportunidade" e "em virtude de prejulgamento pelo plenário ou comissão, em outra ação". A prejudicialidade implica arquivamento definitivo da proposição, mas há recurso que permite contestar essa decisão, como será visto adiante.

13 São tidas como importantes: a medida provisória após seu $45^{\circ}$ dia de edição; matéria urgente do Presidente da República com prazo de tramitação esgotado; urgências definidas pelos líderes e senadores; projeto de decreto legislativo sobre matéria não-postergável ou improrrogável. As matérias devem ter sido protocoladas na Secretaria Geral até 30 de novembro do ano anterior (BRASIL. SENADO FEDERAL, 1970).

14 A sessão legislativa ordinária, na Câmara e no Senado, divide-se em: "pequeno expediente" (60 minutos), "grande expediente" (50 minutos), "ordem do dia" (três horas) e "comunicações parlamentares" (se houver tempo). Não integram esta análise os requerimentos que podem ser apresentados na "ordem do dia" das comissões.
} 
QUADRO 3 - PRERROGATIVAS DOS ATORES LEGISLATIVOS PARA ALTERAR A ORDEM DO DIA E O PROCESSO DE DISCUSSÃO-VOTAÇÃO DAS PROPOSIÇÕES NO PLENÁRIO DA CÂMARADOS DEPUTADOS

\begin{tabular}{|c|c|c|c|c|c|}
\hline \multirow[b]{2}{*}{ PRERROGATIVAS } & \multicolumn{5}{|c|}{ ATORES } \\
\hline & $\begin{array}{l}\text { PRESIDENTE } \\
\text { DA MESA }\end{array}$ & $\begin{array}{l}\text { COLÉGIO } \\
\text { LÍDERES }\end{array}$ & LÍDER & RELATOR & DEPUTADO \\
\hline \multicolumn{6}{|l|}{ Alterações na ordem do dia } \\
\hline $\begin{array}{l}\text { Alterar a ordem de discussão e } \\
\text { votação de matéria sobre as do } \\
\text { mesmo grupo (art. 50, 160) }\end{array}$ & - & $\begin{array}{l}\text { Req. à } \\
\text { Mesa }\end{array}$ & - & - & $\begin{array}{l}\text { Req. } \\
\text { qualquer } \\
\text { deputado à } \\
\text { Mesa }\end{array}$ \\
\hline $\begin{array}{l}\text { Incluir proposição por } \\
\text { encerramento da tramitação nas } \\
\text { comissões ou no plenário (art. 135) }\end{array}$ & - & - & - & - & $\begin{array}{l}\text { Req. autor } \\
\text { ao } \\
\text { presidente }\end{array}$ \\
\hline $\begin{array}{c}\text { Incluir proposição que trata de } \\
\text { relevante e inadiável interesse } \\
\text { nacional (art. 155) (urgência } \\
\text { urgentíssima) }\end{array}$ & - & - & $\begin{array}{l}\text { Req. repres. } \\
\text { maioria ao } \\
\text { plenário }\end{array}$ & - & $\begin{array}{l}\text { Req. maioria } \\
\text { ao plenário }\end{array}$ \\
\hline $\begin{array}{l}\text { Incluir proposição pelo instituto da } \\
\text { urgência (art. 15, 151, 154) }\end{array}$ & $\begin{array}{l}\text { Req. } 2 / 3 \text { ao } \\
\text { plenário }\end{array}$ & - & $\begin{array}{l}\text { Req. repres. } \\
1 / 3 \text { ao } \\
\text { plenário }\end{array}$ & - & $\begin{array}{l}\text { Req. } 1 / 3 \text { ao } \\
\text { plenário }\end{array}$ \\
\hline $\begin{array}{c}\text { Incluir proposição pela dispensa de } \\
\text { interstício, mas com a distribuição } \\
\text { de avulsos (art. 150) }\end{array}$ & - & Automático & - & - & $\begin{array}{l}\text { Req. } 1 / 10 \\
\text { ao plenário }\end{array}$ \\
\hline $\begin{array}{l}\text { Incluir proposição, na Ordem do } \\
\text { Dia seguinte, pelo instituto da } \\
\text { prioridade (art. 15, 158) }\end{array}$ & $\begin{array}{l}\text { Req. Mesa ao } \\
\text { plenário }\end{array}$ & - & - & - & $\begin{array}{l}\text { Req. autor } \\
\text { ao plenário, } \\
\text { apoiado por } \\
1 / 10 \mathrm{da} \\
\text { Casa ou } \\
\text { líderes } \\
\text { repres. } 1 / 10\end{array}$ \\
\hline \multicolumn{6}{|c|}{ Alterações no processo de discussão e votação das proposições } \\
\hline $\begin{array}{l}\text { Adiar discussão e votação de } \\
\text { proposição por até } 10 \text { sessões (art. } \\
107,193 \text { ) }\end{array}$ & - & - & $\begin{array}{l}\text { Req. ao } \\
\text { plenário }\end{array}$ & $\begin{array}{l}\text { Req. ao } \\
\text { plenário }\end{array}$ & $\begin{array}{l}\text { Req. autor } \\
\text { ao plenário }\end{array}$ \\
\hline $\begin{array}{l}\text { Adiar discussão e votação de } \\
\text { proposição em tramitação urgente } \\
\text { (por até } 02 \text { sessões) (art. 177, 193) }\end{array}$ & - & - & $\begin{array}{l}\text { Req. repres. } \\
1 / 10 \text { ao } \\
\text { plenário }\end{array}$ & - & $\begin{array}{l}\text { Req. } 1 / 10 \\
\text { ao plenário }\end{array}$ \\
\hline $\begin{array}{l}\text { Destacar emendas para votação } \\
\text { em separado (altera norma de que } \\
\text { emendas com parecer semelhante } \\
\text { são votadas em globo) (art. 189) }\end{array}$ & - & - & - & - & $\begin{array}{l}\text { Req. } \\
\text { qualquer } \\
\text { deputado ao } \\
\text { plenário }\end{array}$ \\
\hline $\begin{array}{c}\text { Destacar parte de proposição, } \\
\text { emenda e subemenda, etc. para } \\
\text { votação em separado ou para } \\
\text { tornar emenda projeto autônomo } \\
\text { (art. 161) }\end{array}$ & - & - & $\begin{array}{l}\text { Req. repres. } \\
1 / 10 \text { ao } \\
\text { plenário }\end{array}$ & - & $\begin{array}{l}\text { Req. } 1 / 10 \\
\text { ao plenário }\end{array}$ \\
\hline $\begin{array}{l}\text { Dispensar discussão de } \\
\text { proposição com pareceres } \\
\text { favoráveis (art. 167) }\end{array}$ & - & - & $\begin{array}{l}\text { Req. líder ao } \\
\text { plenário }\end{array}$ & - & - \\
\hline Encerrar discussão (art. 178) & - & - & $\begin{array}{l}\text { Req. repres. } \\
5 / 100 \text { ao } \\
\text { plenário }\end{array}$ & - & $\begin{array}{l}\text { Req. } 5 / 100 \\
\text { ao plenário }\end{array}$ \\
\hline
\end{tabular}


Encerrar discussão (art. 178)

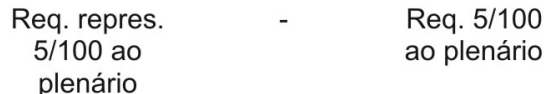

Retirar a proposição em qualquer

estágio da tramitação (art. 104)

Req. autor à Mesa ou ao plenário

Submeter emendas e subemendas

à votação em globo (art. 191)

Req. qualquer deputado à Mesa ou ao plenário

Submeter matéria à votação Automático

Req. repres. Req. 6/100 nominal (art. 10, 185)

$6 / 100$ ao presidente presidente

Submeter matéria à votação nominal antes do decurso de 01 (uma) hora da última (art. 185)

Submeter matéria ä votação

Automático

Req; repres. $1 / 10$ ao

Req. 1/10 plenário ao plenário

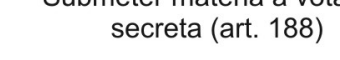

Submeter matéria não-emendada, no $2^{\circ}$ turno, à votação (art. 149)
Req. repres $1 / 10$ ao plenário

Req. $1 / 10$ ao plenário

FONTE: BRASIL. Câmara dos Deputados (1989).

NOTAS: req.: requerimento; repres.: representante.

QUADRO 4 - PRERROGATIVAS DOS ATORES LEGISLATIVOS PARA ALTERAR A ORDEM DO DIA E O PROCESSO DE DISCUSSÃO E VOTAÇÃO DAS PROPOSIÇÕES NO PLENÁRIO DO SENADO FEDERAL

\begin{tabular}{|c|c|c|c|c|}
\hline \multirow{2}{*}{ PRERROGATIVAS } & \multicolumn{4}{|c|}{ ATORES } \\
\hline & $\begin{array}{l}\text { PRESIDENTE } \\
\text { DA MESA }\end{array}$ & LÍDER & RELATOR & SENADOR \\
\hline \multicolumn{5}{|l|}{ Alterações na ordem do dia } \\
\hline $\begin{array}{c}\text { Alterar a ordem de discussão e } \\
\text { votação de matéria sobre as demais } \\
\text { (art. 311) }\end{array}$ & - & - & - & $\begin{array}{l}\text { Req. qualquer } \\
\text { senador ao } \\
\text { plenário }\end{array}$ \\
\hline $\begin{array}{c}\text { Incluir qualquer matéria em } \\
\text { condições de nela figurar (avulsos } \\
\text { publicados com } 10 \text { dias de } \\
\text { antecedência, protocoladas até } 30 \\
\text { de novembro na Secretaria) (art. } \\
167,169,171,214 \text { ) }\end{array}$ & - & - & - & $\begin{array}{l}\text { Req. qualquer } \\
\text { senador ao } \\
\text { presidente }\end{array}$ \\
\hline $\begin{array}{l}\text { Incluir proposição com prazo para } \\
\text { parecer esgotado (art. 121, 172) }\end{array}$ & Automático & - & - & $\begin{array}{l}\text { Req. qualquer } \\
\text { senador ao } \\
\text { plenário } \\
\text { quando faltar } \\
\text { apenas um } \\
\text { parecer }\end{array}$ \\
\hline $\begin{array}{l}\text { Incluir proposição que está a mais } \\
\text { de cinco dias em tramitação, pela } \\
\text { dispensa de interstício e de } \\
\text { distribuição prévia de avulsos (art. } \\
\text { 281) }\end{array}$ & - & - & - & $\begin{array}{l}\text { Req. qualquer } \\
\text { senador ao } \\
\text { plenário }\end{array}$ \\
\hline
\end{tabular}




\begin{tabular}{|c|c|c|c|c|}
\hline $\begin{array}{l}\text { Incluir proposição que está a mais } \\
\text { de cinco dias em tramitação, pela } \\
\text { dispensa de interstício e de } \\
\text { distribuição prévia de avulsos (art. } \\
\text { 281) }\end{array}$ & - & - & - & $\begin{array}{l}\text { Req. qualquer } \\
\text { senador ao } \\
\text { plenário }\end{array}$ \\
\hline $\begin{array}{l}\text { Incluir matéria que envolva perigo } \\
\text { para segurança nacional ou } \\
\text { providência para atender } \\
\text { calamidade pública (art. } 336, \text { I) }\end{array}$ & $\begin{array}{l}\text { Req. Mesa ao } \\
\text { plenário }\end{array}$ & $\begin{array}{l}\text { Req. de } \\
\text { representantes } \\
\text { da maioria ao } \\
\text { plenário }\end{array}$ & - & $\begin{array}{l}\text { Req. maioria } \\
\text { ao plenário }\end{array}$ \\
\hline $\begin{array}{c}\text { Incluir matéria dentro de duas } \\
\text { sessões ordinárias (art. } 336,339 \text {, } \\
340,345)\end{array}$ & - & $\begin{array}{l}\text { Req. de } \\
\text { representantes } \\
\text { de } 2 / 3 \text { ao } \\
\text { plenário }\end{array}$ & - & $\begin{array}{l}\text { Req. } 2 / 3 \text { ao } \\
\text { plenário }\end{array}$ \\
\hline $\begin{array}{l}\text { Incluir matéria pendente de parecer, } \\
\text { dentro de cinco sessões ordinárias } \\
\text { após a apresentação do } \\
\text { requerimento (art. 336, 339, 340, } \\
\text { 345). }\end{array}$ & - & $\begin{array}{l}\text { Req. de } \\
\text { representantes } \\
\text { de } 1 / 4 \text { ao } \\
\text { plenário }\end{array}$ & - & $\begin{array}{l}\text { Req. } 1 / 4 \text { ao } \\
\text { plenário }\end{array}$ \\
\hline \multicolumn{5}{|c|}{ Alterações no processo de discussão e votação das proposições } \\
\hline $\begin{array}{l}\text { Adiar discussão e votação por } 30 \text { dias } \\
\text { (prorrogável por mais 30) (art. 279, } \\
\text { 315) }\end{array}$ & - & - & - & $\begin{array}{l}\text { Req. qualquer } \\
\text { senador ao } \\
\text { plenário }\end{array}$ \\
\hline $\begin{array}{l}\text { Adiar discussão e votação de } \\
\text { proposição em regime de urgência por } \\
24 \text { horas (art. 375) }\end{array}$ & - & - & - & - \\
\hline $\begin{array}{c}\text { Apreciar } 1^{\circ} \text { parecer de proposições } \\
\text { com pareceres discordantes (art. 227, } \\
\text { 229) }\end{array}$ & - & - & - & $\begin{array}{l}\text { Req. qualquer } \\
\text { senador ao } \\
\text { plenário }\end{array}$ \\
\hline $\begin{array}{c}\text { Destacar emenda ou parte da } \\
\text { proposição para votação em separado } \\
\text { ou para constituir projeto autônomo } \\
\text { (art. } 300,312)\end{array}$ & - & - & - & $\begin{array}{l}\text { Req. qualquer } \\
\text { senador ao } \\
\text { plenário }\end{array}$ \\
\hline $\begin{array}{l}\text { Dispensar discussão de proposição } \\
\text { com pareceres favoráveis (art. 276) }\end{array}$ & - & $\begin{array}{l}\text { Req. de líder ao } \\
\text { plenário }\end{array}$ & - & - \\
\hline $\begin{array}{c}\text { Dispensar parecer escrito da primeira } \\
\text { comissão por esgotamento de prazo } \\
\text { (art. 119) }\end{array}$ & - & - & - & $\begin{array}{l}\text { Req. qualquer } \\
\text { senador ao } \\
\text { plenário }\end{array}$ \\
\hline
\end{tabular}

FONTE: BRASIL, Senado Federal (1970).

NOTAS: req.: requerimento; repres.: representante.

$\mathrm{Na}$ comparação das prerrogativas dos atores para alterar a pauta da "ordem do dia" e o processo de discussão e votação das proposições, nos Plenários da Câmara e do Senado ${ }^{14}$, a primeira observação a ser feita diz respeito à similaridade dos dois regimentos. No que se refere às alterações na pauta, deputados e senadores podem apresentar, à Mesa, ao seu presidente ou ao plenário, requerimentos com praticamente os mesmos objetivos: inclusão de proposições por meio de requerimentos de urgência ou prioridade, alteração na ordem de discussão e votação das proposições já incluídas. Nos requerimentos destinados a alterar o processo de discussão e votação, constatam-se as seguintes semelhanças: adiamento de discussão e votação, destaque na votação, dispensa e encerramento de discussão, votação nominal, retirada de proposição. Há, no entanto, duas diferenças a serem destacadas: 1) na Câmara, há dois tipos de requerimentos para destaque e dois para submeter matéria à votação nominal; no Senado, há apenas um tipo de cada; 2) no Senado, há maior diversidade de requerimentos de natureza aparentemente burocrática que na Câmara. 
Essas diferenças parecem estar relacionadas com dois fatores que distinguem o processo legislativo entre as duas Casas. O primeiro diz respeito à centralidade do sistema de comissões. No Senado, permite-se que um número significativamente maior de tipos de proposição tenha votação conclusiva nas comissões ${ }^{15} \mathrm{e} o$ presidente da Casa, depois de ouvir as lideranças, pode ampliar essa competência das comissões, abrangendo, inclusive, projetos em tramitação urgente ou de competência privativa do Senado e do Congresso (art. 91), o que é expressamente proibido no Regimento da Câmara (art. 24). A maior centralidade do sistema de comissões no Senado explica a maior diversidade dos requerimentos que alteram o processo de discussão e votação das proposições. O segundo fator está relacionado com o maior poder de veto dos senadores, considerados individualmente, em relação ao dos deputados. Portanto, nesse aspecto, encontramos o mesmo padrão constatado por estudos sobre outras Câmaras Altas (KIEWIET \& MCCUBBINS, 1991; MALTZMAN \& SMITH, 1995; BINDER, 1997). As maiores exigências feitas aos senadores são a assinatura de três deles no requerimento para votação nominal e a do autor no requerimento para retirar proposição de tramitação. Os outros tipos de requerimento podem ser feitos por "qualquer senador"16. Na Câmara, as exigências são maiores: "qualquer deputado" pode requerer apenas a votação "em globo"17, de emendas e subemendas, e a votação destacada de emendas com pareceres semelhantes. Para requerer outros tipos de alteração no processo de discussão e votação das proposições, exige-se a assinatura de grupos de deputados que variam de $5 / 100$ a $1 / 10$ da representação.

\footnotetext{
15 A votação conclusiva significa que o projeto de lei não será votado no plenário da Casa legislativa. Para contestar o resultado da votação nas comissões, os parlamentares devem interpor recurso, solicitando nova apreciação do projeto, como será visto abaixo.

16 O Regimento do Senado não explicita o autor que tem a prerrogativa de requerer adiamento, por 24 horas, da discussão e votação de projeto em tramitação urgente. A falta dessa informação está sendo entendida aqui como indício de sua pouca importância e, assim, que o requerimento pode ser feito também por "qualquer senador".

17 O termo votação "em globo" significa votação conjunta, contrapondo-se à votação destacada ou separada das emendas que foram oferecidas a uma mesma proposição.
}

Essa maior exigência está relacionada com a delegação mais ampla de prerrogativas aos líderes na Câmara, se comparada com a que vigora no Senado. Todos os requerimentos para alterar o processo de discussão e votação das proposições que exigem a assinatura de grupos de deputados podem ser assinados também por líderes que os representem. No Senado, para esse mesmo conjunto de requerimentos, a única delegação aos líderes é a de requerer dispensa de discussão de proposição com pareceres favoráveis. Apenas para alterar a "ordem do dia", especificamente para alterar o rito de tramitação das proposições (urgência, prioridade), em que se exige, como na Câmara, um número maior de parlamentares, também se permite aos líderes substituírem os senadores.

Considerando que diversos dos requerimentos listados são utilizados pelos parlamentares para influenciar o conteúdo e o ritmo do processo legislativo e para expor os adversários, aumentando assim os custos políticos de suas decisões, podese concluir que as preferências e as oportunidades de influência política de um deputado estão mais sujeitas à boa vontade das lideranças que as de um senador. De qualquer forma, é importante lembrar que a delegação permite aos parlamentares, especialmente na Câmara, diminuírem os custos de transação do processo legislativo e, assim, maximizarem suas preferências políticas (MIRANDA, 2009). Para isso, suas preferências devem estar, no entanto, alinhadas com as de seus líderes ${ }^{18}$.

$\mathrm{Na}$ prática, entre os requerimentos mais utilizados para expor as estratégias dos adversários, estão aqueles que solicitam votação nominal e destaque para votação em separado. A ampla utilização do requerimento de destaque pelos partidos da oposição durante a Reforma da

\footnotetext{
18 A maior dependência que os deputados têm de seus líderes em relação aos senadores e as diferenças no processo legislativo não resultam em diferenças estatisticamente significativas na disciplina dos partidos nas votações nominais entre as duas casas legislativas (cf. MIRANDA, 2008). Diferenças significativas na disciplina surgem apenas entre os partidos em cada Casa legislativa e explicamse por fatores relacionados às arenas eleitoral e organizacional, conforme analisado em Miranda (2009)
} 
Previdência, em 1995 (FIQUEIREDO \& LIMONGI, 1999; MELO \& ANASTASIA, 2005), ensejou mudanças no Regimento da Câmara, em 1996, que limitaram seu número ao tamanho das bancadas $^{19}$. Requerimentos que extrapolam o permitido passaram a depender da aprovação do plenário (art. 161). Os outros requerimentos são utilizados para protelar ou acelerar a tramitação das proposições, constituindo-se em recursos importantes nas mãos de parlamentares e lideranças. Entre esses instrumentos de maximização das preferências em torno de políticas, também adquirem destaque o uso estratégico da palavra, a obstrução parlamentar, que provoca a falta de quorum de votação, e, por fim, a apresentação de emendas, que enseja o retorno das proposições às comissões para elaboração de parecer (FIGUEIREDO \& LIMONGI, 1999; INÁCIO, 2006; 2007; SANTOS, 2007).

Além de facilitar as estratégias dos parlamentares destinadas a alterar a pauta da "ordem do dia" e o processo de discussão e votação das proposições, os líderes também facilitam suas iniciativas de convocação e alteração da dinâmica das sessões e de criação de comissões. Também nesse aspecto, as prerrogativas das lideranças são mais importantes para os deputados do que para os senadores. O Quadro 5 traz a configuração dos atores que possuem essas prerrogativas na Câmara dos Deputados e no Senado Federal.

QUADRO 5 - PRERROGATIVAS DOS ATORES PARA CONVOCAR E ALTERAR DINÂMICA DE SESSÕES E COMISSÕES NA CÂMARA E NO SENADO

\begin{tabular}{|c|c|c|c|c|c|}
\hline \multirow[b]{2}{*}{ PRERROGATIVAS } & \multicolumn{5}{|c|}{ ATORES } \\
\hline & $\begin{array}{l}\text { PRESIDENTE } \\
\text { DA MESA }\end{array}$ & $\begin{array}{l}\text { COLÉGIO } \\
\text { LÍDERES }\end{array}$ & LÍDER & RELATOR & PARLAMENTAR \\
\hline \multicolumn{6}{|c|}{ Câmara dos Deputados } \\
\hline $\begin{array}{l}\text { Convocar sessão secreta (art. } \\
92 \text { ) }\end{array}$ & - & Automático & $\begin{array}{l}\text { Req. de } \\
\text { líderes ao } \\
\text { plenário }\end{array}$ & - & $\begin{array}{l}\text { Automaticamente } \\
\text { a pedido de } 1 / 3 ; \\
\text { Req. } 1 / 5 \text { ao } \\
\text { plenário }\end{array}$ \\
\hline $\begin{array}{l}\text { Convocar sessão solene (art. } \\
68 \text { ) }\end{array}$ & De ofício & - & $\begin{array}{c}\text { Req. repres. } \\
1 / 10 \text { ao } \\
\text { plenário }\end{array}$ & - & $\begin{array}{l}\text { Req. } 1 / 10 \text { ao } \\
\text { plenário }\end{array}$ \\
\hline $\begin{array}{l}\text { Convocar sessão } \\
\text { extraordinária e prorrogação } \\
\text { do prazo das sessões } \\
\text { ordinárias e (art. } 67,72,84)\end{array}$ & De ofício & Automático & - & - & - \\
\hline $\begin{array}{c}\text { Convocar sessão } \\
\text { extraordinária para discussão } \\
\text { e votação de matéria (art. 66) }\end{array}$ & $\begin{array}{l}\text { De ofício ou a } \\
\text { req. }\end{array}$ & Automático & - & - & $\begin{array}{l}\text { Req. } 1 / 3 \text { ao } \\
\text { plenário }\end{array}$ \\
\hline $\begin{array}{c}\text { Criar comissão especial (art. } \\
34 \text { ) }\end{array}$ & $\begin{array}{c}\text { De ofício ou a } \\
\text { req. }\end{array}$ & - & $\begin{array}{l}\text { Req. ao } \\
\text { presidente }\end{array}$ & - & - \\
\hline $\begin{array}{l}\text { Criar CPI (máximo de cinco } \\
\text { em funcionamento) (art. } 35 \text { ) }\end{array}$ & - & - & - & - & $\begin{array}{l}\text { Req. } 1 / 3 \text { ao } \\
\text { presidente }\end{array}$ \\
\hline $\begin{array}{l}\text { Criar comissão externa (art. } \\
\text { 38) (quando houver ônus) }\end{array}$ & De ofício & - & - & - & $\begin{array}{l}\text { Req. qualquer } \\
\text { deputado ao } \\
\text { plenário }\end{array}$ \\
\hline $\begin{array}{c}\text { Prorrogar prazo } \\
\text { funcionamento de CPI (até a } \\
\text { metade) (art. 35) }\end{array}$ & - & - & - & - & Req. ao plenário \\
\hline $\begin{array}{l}\text { Transformar sessão ordinária } \\
\text { em comissão geral (art. 91) }\end{array}$ & $\begin{array}{l}\text { Automatica- } \\
\text { mente }\end{array}$ & $\begin{array}{l}\text { Req. ao } \\
\text { presidente }\end{array}$ & - & - & $\begin{array}{l}\text { Req. } 1 / 3 \text { ao } \\
\text { presidente }\end{array}$ \\
\hline
\end{tabular}

19 Partidos com mais de cinco deputados têm direito a um destaque a cada fração de 24 deputados. 


\begin{tabular}{|c|c|c|c|c|c|}
\hline \multicolumn{6}{|c|}{ Senado Federal } \\
\hline $\begin{array}{l}\text { Autorizar missão externa ou } \\
\text { no país, ou de representação } \\
\text { da casa, de senador, se } \\
\text { houver ônus (art.40) }\end{array}$ & $\begin{array}{l}\text { Req. ao } \\
\text { plenário. }\end{array}$ & - & $\begin{array}{l}\text { Req. ao } \\
\text { plenário }\end{array}$ & - & $\begin{array}{l}\text { Req. qualquer } \\
\text { senador ao } \\
\text { plenário }\end{array}$ \\
\hline $\begin{array}{l}\text { Convocar sessão secreta (art. } \\
48,133,135,139,190,197 \text { ) }\end{array}$ & De ofício & - & - & - & $\begin{array}{l}\text { Req. qualquer } \\
\text { senador ao } \\
\text { plenário }\end{array}$ \\
\hline $\begin{array}{c}\text { Convocar sessão especial } \\
\text { (art. 199) }\end{array}$ & De ofício & - & - & - & $\begin{array}{l}\text { Req. seis } \\
\text { senadores ao } \\
\text { plenário }\end{array}$ \\
\hline $\begin{array}{l}\text { Convocar sessão } \\
\text { extraordinária (art. 154, 187) }\end{array}$ & De ofício & - & - & - & - \\
\hline $\begin{array}{l}\text { Criar comissão externa (art. } \\
\qquad 67,75)\end{array}$ & $\begin{array}{l}\text { De ofício ou } \\
\text { req.ao } \\
\text { plenário }\end{array}$ & - & - & - & $\begin{array}{l}\text { Req. de qualquer } \\
\text { senador ao } \\
\text { plenário }\end{array}$ \\
\hline Criar CPI (art. 145) & - & - & - & - & $\begin{array}{l}\text { Req. } 1 / 3 \text { ao } \\
\text { presidente }\end{array}$ \\
\hline $\begin{array}{l}\text { Prorrogar tempo da sessão } \\
\text { ordinária (art. } 43,48,180, \\
\qquad 215,288)\end{array}$ & De ofício & - & - & - & $\begin{array}{l}\text { Req. qualquer } \\
\text { senador ao } \\
\text { plenário }\end{array}$ \\
\hline $\begin{array}{c}\text { Prorrogar prazo de } \\
\text { funcionamento de CPI (art. } \\
152)\end{array}$ & - & - & - & - & $\begin{array}{l}\text { Req. } 1 / 3 \text { ao } \\
\text { presidente }\end{array}$ \\
\hline $\begin{array}{l}\text { Transformar sessão ordinária } \\
\text { em sessão especial (art. 199) }\end{array}$ & De ofício & - & - & - & $\begin{array}{c}\text { Req. seis } \\
\text { senadores ao } \\
\text { plenário }\end{array}$ \\
\hline
\end{tabular}

FONTE: BRASIL. Câmara dos Deputados (1989) e BRASIL. Senado Federal (1970).

NOTAS: req.: requerimento; repres.: representante.

$\mathrm{Na}$ avaliação das prerrogativas para criar comissões temporárias (comissão especial, comissão externa, comissão parlamentar de inquérito), convocar sessões especiais ou extraordinárias e alterar o formato das sessões legislativas, constata-se que a participação das lideranças é mais pontual. No Senado, os líderes contam apenas com a prerrogativa de requerer autorização para instalar missão ou representação externa, o que "qualquer senador" e "qualquer deputado" podem fazer. Na Câmara, os líderes podem facilitar a convocação de sessão secreta e sessão solene, o que é permitido também aos deputados. A criação de comissão especial, não prevista no regimento do Senado, é prerrogativa exclusiva dos líderes na Câmara ${ }^{20}$. Assim, tendose em vista essa exclusividade, pode-se dizer que, também nesse conjunto de iniciativas, os

\footnotetext{
20 Na prática, as comissões especiais também existem no Senado. No regimento da Câmara, prevê-se a constituição dessas comissões para apreciar propostas de emendas à Constituição, projetos de código e matérias que demandam apreciação em mais de três comissões temáticas. Nesse caso, metade dos membros deve pertencer às comissões permanentes que tratam da matéria (art. 34).
}

deputados são mais dependentes dos líderes do que os senadores.

Cabe ressaltar que a regulamentação do requerimento para instalação de Comissão Parlamentar de Inquérito (CPI) é constitucional, não apresentando, por isso, diferença entre as Casas. Ele deve ser assinado por $1 / 3$ da Casa e dirigido ao presidente da Mesa Diretora. A prorrogação do prazo de funcionamento desse tipo de comissão é, no entanto, diferente entre as duas Casas: na Câmara, o requerimento deve ser dirigido ao presidente e não se formaliza o número de assinaturas necessárias; no Senado, o requerimento deve estar assinado por um $1 / 3$ da Casa e deve ser dirigido ao plenário. Os líderes não participam dessas iniciativas nem na Câmara nem no Senado.

A delegação às lideranças partidárias, à Mesa e às comissões não é incondicional. Os líderes, conforme visto acima, podem ser destituídos a qualquer tempo por suas bancadas. A destituição dos ocupantes dos outros cargos e a contestação de suas decisões demandam maior ou menor coordenação, o que pode estimular a inércia, especificamente se os custos forem maiores do que os benefícios da mudança. De qualquer forma, 
as prerrogativas de contestação das decisões dos

são apresentadas no Quadro 6.

diversos atores estão previstas nos regimentos e

QUADRO 6 - PRERROGATIVAS DOS ATORES LEGISLATIVOS PARA CONTESTAR DECISÕES DE ÓRGÃOS INTERNOS

\begin{tabular}{|c|c|c|}
\hline \multirow[t]{2}{*}{ PRERROGATIVAS } & \multicolumn{2}{|r|}{ ATORES } \\
\hline & LDERR & PARLAMENTAR \\
\hline \multicolumn{3}{|c|}{ Câmara dos Deputados } \\
\hline $\begin{array}{l}\text { Requerer apreciação pelo plenário de aprovação } \\
\text { conclusiva de projeto pelas comissões (art. } 58,59,132)\end{array}$ & - & Recurso de $1 / 10$ ao plenário \\
\hline $\begin{array}{c}\text { Requerer apreciação pelo plenário de parecer contrário } \\
\text { à emenda, elaborados pelas CCJ, CFT ou comissão } \\
\text { especial (art. 189) }\end{array}$ & - & Recurso ao plenário \\
\hline $\begin{array}{l}\text { Contestar declaração do presidente de prejudicialidade } \\
\qquad \text { (art. 164) }\end{array}$ & - & $\begin{array}{l}\text { Recurso do autor ao } \\
\text { plenário, que ouvirá CCJ }\end{array}$ \\
\hline $\begin{array}{l}\text { Contestar recusa de requerimento pela presidência para } \\
\qquad \text { constituição de CPI (art. 35) }\end{array}$ & - & $\begin{array}{l}\text { Recurso do autor ao } \\
\text { plenário, que ouvirá CCJ }\end{array}$ \\
\hline $\begin{array}{c}\text { Contestar indeferimento de requerimentos pela } \\
\text { presidência (art. 114) }\end{array}$ & - & $\begin{array}{l}\text { Recurso do autor ao } \\
\text { plenário }\end{array}$ \\
\hline \multicolumn{3}{|c|}{ Senado Federal } \\
\hline $\begin{array}{l}\text { Requerer apreciação pelo plenário de aprovação } \\
\text { conclusiva de projeto pelas comissões (art. 91) }\end{array}$ & - & $\begin{array}{l}\text { Recurso de } 1 / 10 \text { ao } \\
\text { presidente }\end{array}$ \\
\hline $\begin{array}{l}\text { Requerer apreciação pelo plenário de recusa de } \\
\text { emenda pela CCJ (apenas se não for unânime o } \\
\text { parecer) (art. 300) }\end{array}$ & $\begin{array}{l}\text { Requerimento de } \\
\text { representante da } \\
\text { maioria ao plenário }\end{array}$ & - \\
\hline $\begin{array}{c}\text { Requerer apreciação pelo plenário de emendas a } \\
\text { projetos do poder Executivo em tramitação urgente nas } \\
\text { comissões (art. 124) }\end{array}$ & - & Recurso de $1 / 10$ ao plenário \\
\hline $\begin{array}{l}\text { Contestar declaração do presidente de prejudicialidade } \\
\qquad \text { (art. 334) }\end{array}$ & - & $\begin{array}{l}\text { Recurso ao plenário que } \\
\text { ouvirá CCJ }\end{array}$ \\
\hline $\begin{array}{l}\text { Contestar rejeição de projetos com pareceres contrários } \\
\text { nas comissões (contraria o arquivamento) (art. 254) }\end{array}$ & - & Recurso de $1 / 10$ ao plenário \\
\hline $\begin{array}{l}\text { Submeter matéria de competência terminativa das } \\
\text { comissões a regime de urgência (art. 336) }\end{array}$ & - & Recurso de $1 / 10$ ao plenário \\
\hline
\end{tabular}

FONTE: BRASIL. Câmara dos Deputados (1989) e BRASIL. Senado Federal (1970).

NOTAS: Req.: Requerimento; repres.: representante; siglas: CCJ: Comissão de Constituição e Justiça e Cidadania; CFT: Comissão de Finanças e Tributação. 
As possibilidades de contestação das decisões dos diversos órgãos também espelham as diferenças do processo legislativo entre as duas Casas. A primeira delas relaciona-se com a centralidade das comissões no Senado, mencionada acima, o que enseja a disponibilidade de mais recursos aos senadores para contestar suas decisões, se comparados aos que estão disponíveis aos deputados. Vejamos.

Deputados podem contestar os pareceres que rejeitam emendas, elaborados pela Comissão de Constituição e Justiça e pela Comissão de Finanças e Tributação, enquanto os senadores podem contestar, além dos pareceres sobre emendas, elaborados pela Comissão de Constituição e Justiça, o que deve ser feito apenas por intermédio dos líderes, os pareceres sobre projetos elaborados por todas as outras comissões. Os senadores podem ainda submeter matéria de competência terminativa das comissões a regime de urgência e requerer a apreciação pelo plenário das emendas oferecidas aos projetos do poder Executivo que estão sujeitos a esse regime nas comissões. Essa prerrogativa permite que eles "derrubem" pareceres contrários e, assim, impeçam o arquivamento dessas matérias pelas comissões. Essa possibilidade está aberta também aos deputados, posto que as emendas aos projetos em tramitação urgente são oferecidas em plenário, em que também são votados os pareceres.

A avaliação das possibilidades de interposição de recursos indica também um poder maior do presidente do Senado frente aos senadores, se comparado ao poder do presidente da Câmara frente aos deputados. Estes podem contestar a declaração de que a proposição está prejudicada, o que é permitido também no Senado, e o indeferimento de requerimento, inclusive aqueles para abertura de comissão parlamentar de inquérito. Além disso, o recurso para que o plenário aprecie votação conclusiva das comissões, que na Câmara é votado pelo plenário, deve ser encaminhado ao presidente no Senado. Em todas as outras situações, nas duas Casas, a atribuição de votar recursos é do plenário.

Cabe destacar, por fim, que nem deputados nem senadores contam com facilidades para contestar decisões dos órgãos internos, a não ser no caso do recurso contra a rejeição de emenda pela Comissão de Constituição e Justiça, que pode ser interposto, no Senado, apenas pelos líderes. Em todas as outras iniciativas, os parlamentares devem arcar com os custos de transação que as diversas iniciativas implicam: convencimento dos pares, coleta de assinaturas, trâmites burocráticos e, eventualmente, constrangimentos políticos.

Por fim, os líderes possuem também prerrogativas para coordenar as preferências políticas, mais especificamente, para influenciar as decisões de voto dos parlamentares pelo uso da palavra durante a "ordem do dia". Nesse aspecto, como nos que foram analisados acima, e especialmente porque estamos tratando de um órgão colegiado de deliberação, eles competem com outros atores. Essas prerrogativas podem ser avaliadas no Quadro 7, em que se faz o mapeamento dos atores que podem usar a palavra durante a "ordem do dia" nas duas Casas.

QUADRO 7 - PRERROGATIVAS DOS ATORES PARA O USO DA PALAVRA DURANTE A ORDEM DO DIANA CÂMARA DOS DEPUTADOS E SENADO FEDERAL

\begin{tabular}{|c|c|c|c|c|}
\hline \multirow[t]{2}{*}{ PRERROGATIVA } & \multicolumn{4}{|c|}{ ATORES } \\
\hline & PRESIDENTE & LÍDER & RELATOR & PARLAMENTAR \\
\hline \multicolumn{5}{|c|}{ Câmara dos Deputados } \\
\hline Apartear (art. 176) & - & - & - & $\begin{array}{c}\text { Qualquer deputado com } \\
\text { brevidade (a qualquer } \\
\text { tempo) }\end{array}$ \\
\hline $\begin{array}{l}\text { Discutir ou apresentar proposição ou } \\
\text { parecer (art. 57, 174) }\end{array}$ & - & - & Cinco minutos & $\begin{array}{c}\text { Autor e mais dois } \\
\text { deputados por cinco } \\
\text { minutos }\end{array}$ \\
\hline
\end{tabular}




\begin{tabular}{|c|c|c|c|c|}
\hline $\begin{array}{l}\text { Discutir redação final de proposição } \\
\text { emendada em sua última ou única } \\
\text { discussão (art. 198) }\end{array}$ & - & - & Cinco minutos & $\begin{array}{l}\text { Autor e um orador contra } \\
\text { por cinco minutos }\end{array}$ \\
\hline $\begin{array}{l}\text { Encaminhar votação de } \\
\text { requerimento de urgência (art. 154) }\end{array}$ & - & $\begin{array}{l}\text { Cinco } \\
\text { minutos }\end{array}$ & $\begin{array}{l}\text { Cinco minutos } \\
\text { (relator ou } \\
\text { deputado } \\
\text { contrário) }\end{array}$ & Autor por cinco minutos \\
\hline $\begin{array}{l}\text { Encaminhar votação de proposições } \\
\qquad\left(\text { art. } 9^{\circ}, 10\right)\end{array}$ & - & Um minuto & $\begin{array}{l}\text { Cinco minutos. } \\
\text { (pode falar } \\
\text { mais de uma } \\
\text { vez) }\end{array}$ & $\begin{array}{c}\text { Autor e mais dois } \\
\text { deputados (contra e a } \\
\text { favor) por cinco minutos } \\
\text { cada }\end{array}$ \\
\hline $\begin{array}{l}\text { Fazer comunicações de interesse do } \\
\text { país }\left(\text { art. } 9^{\circ}, 10,66,89\right)\end{array}$ & $\begin{array}{l}\text { A qualquer } \\
\text { tempo }\end{array}$ & $\begin{array}{l}\text { A qualquer } \\
\text { tempo }\end{array}$ & - & - \\
\hline $\begin{array}{l}\text { Interpor questões de ordem e fazer } \\
\text { reclamações (art. } 95 \text { e 96) }\end{array}$ & - & - & - & $\begin{array}{l}\text { Qualquer deputado por } \\
\text { três minutos }\end{array}$ \\
\hline $\begin{array}{c}\text { Encaminhar votação de projeto por } \\
\text { partes (art. 192) }\end{array}$ & - & Um minuto & - & $\begin{array}{l}\text { Um orador contra e outro } \\
\text { a favor por cinco minutos }\end{array}$ \\
\hline $\begin{array}{l}\text { Encaminhar votação de emenda } \\
\text { destacada (art. 192) }\end{array}$ & - & - & Cinco minutos & $\begin{array}{l}\text { Autor da emenda por } \\
\text { cinco minutos }\end{array}$ \\
\hline $\begin{array}{l}\text { Encaminhar votação de } \\
\text { requerimentos (art. 117) }\end{array}$ & - & - & - & $\begin{array}{l}\text { Signatário e um orador } \\
\text { contrário por cinco } \\
\text { minutos }\end{array}$ \\
\hline \multicolumn{5}{|c|}{ Senado Federal } \\
\hline Apartear (art. 14) & - & - & - & $\begin{array}{c}\text { Qualquer senador por dois } \\
\text { minutos (a qualquer } \\
\text { tempo) }\end{array}$ \\
\hline $\begin{array}{l}\text { Discutir proposição (art. 14, 109, } \\
\text { 273) }\end{array}$ & - & Dez minutos & - & - \\
\hline $\begin{array}{l}\text { Discutir a redação final de } \\
\text { proposições (art. 14, 321) }\end{array}$ & - & - & Cinco minutos & $\begin{array}{l}\text { Um senador de cada } \\
\text { partido por cinco minutos }\end{array}$ \\
\hline $\begin{array}{l}\text { Encaminhar votação de } \\
\text { requerimentos de urgência (art. 300, } \\
341,343 \text { ) }\end{array}$ & - & - & - & $\begin{array}{l}\text { Signatário e um } \\
\text { representante de cada } \\
\text { partido por cinco minutos }\end{array}$ \\
\hline $\begin{array}{l}\text { Encaminhar votação de proposições } \\
\qquad(\text { art. 14, 308, 310) }\end{array}$ & - & - & - & $\begin{array}{l}\text { Qualquer senador por } \\
\text { cinco minutos }\end{array}$ \\
\hline $\begin{array}{l}\text { Fazer comunicações de interesse do } \\
\text { Senado e do país (art. 48) }\end{array}$ & $\begin{array}{l}\text { A qualquer } \\
\text { tempo }\end{array}$ & - & - & - \\
\hline $\begin{array}{l}\text { Interpor questões de ordem ou } \\
\text { solicitar informacões sobre a ordem }\end{array}$ & - & - & - & Qualquer senador por \\
\hline
\end{tabular}

FONTE: BRASIL. Câmara dos Deputados (1989) e BRASIL. Senado Federal (1970).

Na comparação das prerrogativas dos atores para o uso da palavra durante a "ordem do dia", constatam-se algumas semelhanças e diferenças entre a Câmara e o Senado e, dentro de cada Casa, entre os atores. Nas duas Casas, o uso irrestrito da palavra é permitido ao presidente, para fazer comunicações de interesse do país, e aos parlamentares para interpor questões de ordem e fazer apartes, nesse caso, se o orador permitir. Para outros objetivos, o uso da fala é restrito.

Na Câmara, reserva-se o tempo para os oradores que efetivamente têm a contribuir no 
sentido de informar o plenário sobre a natureza da proposição e de manifestar posição política definida, contra ou favorável à sua aprovação; no Senado, as oportunidades para "qualquer senador" se manifestar e influenciar a deliberação são maiores. São duas as evidências dessa avaliação: 1) no Senado, os relatores podem formalmente apenas discutir a redação final e oferecer parecer oral; na Câmara, eles podem também encaminhar a votação; 2) na Câmara, o uso da palavra para discutir a proposição e encaminhar sua votação está restrito ao autor e a dois parlamentares, um com posição contrária e outro com posição favorável; no Senado, restrição semelhante ocorre apenas para o encaminhamento de requerimentos de urgência; nos outros casos, "qualquer senador" pode fazê-lo.

No que se refere às prerrogativas das lideranças, também há diferenças. No Senado, elas podem fazer uso irrestrito da palavra para fazer comunicações de interesse partidário e discutir proposição. Com outros objetivos, inclusive para encaminhar a votação, os líderes competem com "qualquer senador". Na Câmara, por outro lado, eles não discutem proposição, mas possuem a prerrogativa de encaminhar a votação. Assim, nos termos dos regimentos, os líderes possuem centralidade nas duas Casas para a difusão da informação. Para a coordenação da ação das bancadas nas votações nominais, a centralidade deles é maior na Câmara, em virtude especialmente da possibilidade de encaminhar o voto sem competir com "qualquer" parlamentar.

Na dinâmica legislativa do Senado, constatamse, no entanto, práticas que diferem do que é previsto no regimento ${ }^{21}$. Pela leitura dos Diários do Senado, percebe-se que os relatores também encaminham o voto quando apresentam seu parecer e que as lideranças partidárias adquiriram, de modo exclusivo, a prerrogativa de "orientar" o voto das bancadas logo após o encaminhamento das votações nominais por "qualquer senador". Essa orientação não é obrigatória, deve ser sucinta e pode ser delegada pelo líder a um membro do partido, desde que comunicada por escrito, e com antecedência, ao presidente da sessão.

\footnotetext{
${ }^{21}$ Cabe salientar que resoluções que regulamentem essas práticas, eventualmente ainda não incorporadas ao Regimento, não foram encontradas na documentação disponibilizada.
}

\section{CONCLUSÕES}

$\mathrm{Na}$ comparação das prerrogativas das lideranças partidárias na Câmara dos Deputados e no Senado Federal, foi verificada, em primeiro lugar, a centralidade das lideranças nas estratégias de maximização das preferências dos parlamentares em torno de políticas e de cargos. Para que o parlamentar comum, ou seja, aquele que não tem perfil para compor a Mesa, Ouvidoria, Procuradoria e outros órgãos similares, possa maximizar suas preferências em torno de cargos, o que significa ser indicado para compor uma comissão hierarquicamente mais valorizada, ele precisa estar alinhado com as preferências de seu líder nas duas Casas. Os parlamentares também dependem das lideranças para maximizar suas preferências em torno de políticas. Ao representar um número maior de parlamentares, os líderes diminuem os custos de transação do processo legislativo, difundindo informações sobre as proposições e coordenando as preferências dos membros de suas bancadas na hora do voto. Eles também diminuem os custos das estratégias parlamentares relacionadas à modificação da agenda legislativa e alteração dos processos de discussão e deliberação das proposições. Para a constituição e alteração no funcionamento de comissões temporárias, convocação e formatação de sessões legislativas, a participação dos líderes é menor, mas ainda importante. Por outro lado, para a contestação das decisões das comissões e da presidência, a delegação aos líderes é ausente na Câmara e bastante pontual no Senado, o que pode dificultar sobremaneira esse tipo de iniciativa por parte dos parlamentares.

Em segundo lugar, foi verificado que a delegação às lideranças é mais importante na Câmara dos Deputados do que no Senado Federal, o que se explica pela diferença na magnitude da representação. Na medida em que a delegação legislativa funciona como mecanismo de superação dos dilemas de ação coletiva, e sendo estes maiores na Câmara do que no Senado, a diferença na delegação legislativa não chega a surpreender. Os senadores, dado que são em menor número do que os deputados, possuem mais capacidade para processar informações e coordenar sua atuação parlamentar de forma descentralizada e dependem menos de seus líderes para ocupar as comissões que lhes interessam, posto que lhes é permitido um acúmulo significativamente maior de cargos. 
A avaliação das prerrogativas das lideranças nas duas Casas permitiu constatar que o poder dos partidos foi reforçado por duas mudanças institucionais substantivas e recentes. A primeira diz respeito à vinculação do critério da proporcionalidade partidária, utilizado para a distribuição de cargos entre os partidos, aos resultados das urnas. As resoluções 34 da Câmara e 35 do Senado, que entraram em vigor em 2007 , proíbem a redistribuição dos cargos entre os partidos ao longo da legislatura, como forma de atualizar a proporcionalidade entre cargos e tamanho das bancadas. Essa atualização foi estimulada pela freqüente, e bastante significativa, alteração no tamanho das bancadas, resultante das mudanças de partido por parte dos parlamentares ao longo da legislatura. Com a entrada em vigor dessas resoluções, a proporcionalidade verificada na instalação da primeira sessão legislativa passa a valer para toda legislatura. A mudança tende a favorecer os partidos de oposição que viam suas bancadas diminuírem logo no primeiro ano do governo e, por isso, ficavam prejudicados pela redistribuição dos cargos. A segunda mudança reforça essas alterações regimentais. Está relacionada com a interpretação do TSE de que o mandato é do partido e não do parlamentar, o que permite que os partidos desfavorecidos pela migração reivindiquem os mandatos dos migrantes.

$\mathrm{Na}$ medida em que apontam para a mesma direção - fortalecimento dos partidos políticos para a coordenação do processo legislativo e distribuição de direitos parlamentares, especialmente o daqueles que preferem não se integrar à base governista -, essas mudanças institucionais abrem possibilidades de ação política potencialmente mais independente do poder Legislativo visà-vis o Executivo. Os fatores que estimularam essas mudanças e seu impacto sobre o comportamento parlamentar, especialmente nas migrações partidárias, e sobre o ritmo e conteúdo da produção legislativa são questões que merecem investigação.

Geralda Luiza de Miranda (geraldaluizam@hotmail.com) é Doutora em Ciência Política pela Universidade Federal de Minas Gerais (UFMG) e Pesquisadora do Instituto de Pesquisa Econômica Aplicada (IPEA) pelo Programa de Pesquisa para o Desenvolvimento Nacional (PNPD).

\section{REFERÊNCIAS BIBLIOGRÁFICAS}

AMORIM NETO, O.; COX, G. \& MCCUBBINS, M. 2003. Agenda Power in Brazil's Câmara dos Deputados (1989-98). World Politics, Princeton, v. 55, n. 4, p. 1-46.

AMORIM NETO, O. \& SANTOS, F. 2003. O segredo ineficiente revisto: o que propõem e o que aprovam os deputados brasileiros. Dados, Rio de Janeiro, v. 46, n. 4, p. 661-698. Disponível em: http://www.scielo.br/pdf/ dados/v46n4/a02v46n4.pdf. Acesso em: 1.set.2010.

BARROS, A. 1975. Representatividade burocrática e eficiência parlamentar - uma contradição? In: MENDES, C. (org.). O legislativo e a tecnocracia. Rio de Janeiro: C. Mendes.

BINDER, S. 1997. Minority Rights, Majority Rule: Partisanship and the development of Congress. Cambridge: Cambridge University.

CAREY, J. 2006. Legislative voting and accountability. Hanover: Dartmouth College.
Disponível em: http://www.dartmouth.edu/ ; jcarey/Research_files/LV\&A\% 20Carey $\% 20$ July\%202007.pdf. Acesso em: 1.fev.2008.

CAREY, J. \& SHUGART, M. 1998. Poder de decreto: chamando os tanques ou usando a caneta. Revista Brasileira de Ciências Sociais, São Paulo, v. 13, n. 37, p.149-184.

COX, G. \& MCCUBBINS, M. 1993. The Legislative Leviathan. Berkeley: University of California.

1995. Bonding, Structure, and the Stability of Political Parties: Party Government in the House. In: SHEPSLE K. \& WEINGAST, B. (eds.). Positive Theories of Congressional Institutions. Ann Arbor: University of Michigan.

FIGUEIREDO, A. 2001. Instituições e política no controle do Executivo. Dados, Rio de Janeiro, v. 44, n. 4, p. 689-727. Disponível em: http://www.scielo.br/scielo.php?script $=$ sci_arttext\&pid=S0011-5258200100040 0002. Acesso em: 1.set.2010. 
FIGUEIREDO, A. \& LIMONGI, F. 1999. Executivo e Legislativo na nova ordem constitucional. Rio de Janeiro: Fundação Getúlio Vargas.

2002. Incentivos eleitorais, partidos e política orçamentária. Dados, Rio de Janeiro, v. 45, n. 2, p. 303-344. Disponível em: http:// www.scielo.br/scielo.php?pid $=$ S0011 52582002000200005\&script $=$ sci_arttext. Acesso em: 1.set.2010.

2006. Poder de agenda na democracia brasileira: desempenho do governo no presidencialismo pluripartidário. In: SOARES, G. \& RENNÓ, L. (orgs.). Reforma Política: lições da história recente. Rio de Janeiro: Fundação Getúlio Vargas.

2007. Instituições políticas e governabilidade: desempenho do governo e apoio legislativo na democracia brasileira. In: MELO, C. \& ALCÂNTARA, M. (orgs.). A democracia brasileira: balanços e perspectivas para o século 21. Belo Horizonte: UFMG.

2008. Política orçamentária no presidencialismo de coalizão. Rio de Janeiro: Fundação Getúlio Vargas.

GOMES, S. 2006. O impacto das regras de organização do processo legislativo no comportamento dos parlamentares: Um estudo de caso da Assembléia Nacional Constituinte (1987-1988). Dados, Rio de Janeiro, v. 49, n. 1, p. 193-224. Disponível em: http:// redalyc.uaemex.mx/pdf/218/21849108.pdf. Acesso em: 1.set.2010.

INÁCIO, M. 2006. Presidencialismo de coalizão e sucesso presidencial na esfera legislativa (1990-2004). Belo Horizonte. Tese (Doutorado em Ciências Humanas). Universidade Federal de Minas Gerais.

2007. Estrutura e funcionamento da Câmara dos Deputados. In: MELO, C. \& ALCÂNTARA, M. (orgs.). A democracia brasileira: balanços e perspectivas para o século 21. Belo Horizonte: UFMG.

KIEWIET, D. \& MCCUBBINS, M. 1991.The Logic of Delegation: Congressional Parties and the Appropriations Process. Chicago: University of Chicago.
LEMOS, L. 2006. El sistema de comisiones en el Senado brasileño: jerarquía y concentración de poderes en la década de 1990. América Latina Hoy, Salamanca, v. 43, p. 155-182.

LIMONGI, F. \& FIGUEIREDO, A. 2005. Processo orçamentário e comportamento legislativo: emendas individuais, apoio ao Executivo e programas de governo. Dados, Rio de Janeiro, v. 48, n. 4, p. 737-776. Disponível em: http:/www.scielo.br/scielo.php?script= sci_arttext\&pid=S0011-52582005000400002. Acesso em: 1.set.2010.

LUPIA, A. \& MCCUBBINS, M. 1995. Who Controls? Information and the Structure of Legislative Decision Making. In: SHEPSLE, K. \& WEINGAST, B. (eds.). Positive Theories of Congressional Institutions. Ann Arbor: University of Michigan.

MALTZMAN, F. \& SMITH, S. 1995. Principals, Goals, Dimensionality and Congressional Committees. In: SHEPSLE, K. \& WEINGAST, B. (eds.). Positive Theories of Congressional Institutions. Ann Arbor: University of Michigan.

MELO, C. 2003. Migração partidária, estratégias de sobrevivência política e governismo na Câmara dos Deputados. In: TAVARES, J. (org.). O sistema partidário na consolidação da democracia brasileira. Brasília: Instituto Teotônio Vilela.

2004. Retirando as cadeiras do lugar: Migração partidária na Câmara dos Deputados (1985-2002). Belo Horizonte: UFMG.

MELO, C. \& ANASTASIA, F. 2005. A reforma da previdência em dois tempos. Dados, Rio de Janeiro, v. 48, n. 2, p. 301-332. Disponível em: http://www.scielo.br/scielo.php?script= sci_arttext\&pid=S0011-52582005000200003. Acesso em: 1.set.2010.

MELO, C. \& MIRANDA, G. 2006. Migrações e partidos no governo Lula. $V$ Encontro da Associação Brasileira de Ciência Política, Belo Horizonte.

MENDES, C. 1975. O Congresso brasileiro pós64: um legislativo para a tecnocracia? In: MENDES, C. (org.). O legislativo e a tecnocracia. Rio de Janeiro: C. Mendes.

MIRANDA, G. 2008. O comportamento dos partidos na Câmara dos Deputados e no 
Senado Federal (1991-2007). Belo Horizonte. Tese (Doutorado em Ciência Política). Universidade Federal de Minas Gerais.

MIRANDA, G. L. 2009. A influência da arena eleitoral sobre o comportamento dos partidos políticos na Câmara dos Deputados e no Senado Federal. Dados, Rio de Janeiro, v. 52, n. 4, p. 911-959. Disponível em: http://www.scielo.br/ pdf/dados/v52n4/v52n4a04.pdf. Acesso em: 10.set.2010.

MÜLLER, G. 2005. Comissões e partidos políticos na Câmara dos Deputados: um estudo sobre os padrões partidários de recrutamento para as comissões permanentes. Dados, Rio de Janeiro, v. 48, n. 1, p. 371-394. Disponível em: http://www.scielo.br/scielo.php?script= sci_arttext\&pid=S0011-52582005000200005. Acesso em: 1.set.2010.

PEREIRA, C. \& MUELLER, B. 2000. Uma teoria da preponderância do Poder Executivo: o sistema de comissões no Legislativo brasileiro. Revista Brasileira de Ciências Sociais, São Paulo, v. 15, n. 43, p. 45-67.

2002. Comportamento estratégico em presidencialismo de coalizão: As relações entre Executivo e Legislativo na elaboração do orçamento brasileiro. Dados, Rio de Janeiro, v. 45, n. 2, p. 265-301. Disponível em: http:// www.scielo.br/scielo.php?pid=S001152582002000200004\&script=sci_arttext. Acesso em: 1.set.2010.

2006. Regras eleitorais e poderes do presidente no Congresso: duas dimensões complementares da capacidade governativa. In: SOARES, G. \& RENNÓ, L. (orgs.). Reforma Política: lições da história recente. Rio de Janeiro: Fundação Getúlio Vargas.

PEREIRA, C. \& RENNÓ, L. 2001. O que é que o reeleito tem? Dinâmicas político-institucionais locais e nacionais nas eleições de 1998 para a Câmara dos Deputados. Dados, Rio de Janeiro, v. 44, n. 2, p. 323-362. Disponível em: http:// www.scielo.br/scielo.php?pid=S0011$52582001000200004 \&$ script $=$ sci_arttext. Acesso em: 1.set.2010.

SANTOS, A. 2001. Sedimentação das lealdades partidárias no Brasil: tendências e descompassos. Revista Brasileira de Ciências Sociais, São Paulo, v. 16, n. 45, p. 69-83.
SANTOS, F. 1997. Patronagem e poder de agenda na política brasileira. Dados, Rio de Janeiro, v. 40, n. 3, p. 465-492. Disponível em: http:// www.scielo.br/scielo.php?pid=S0011$52581997000300007 \&$ script=sci_arttext. Acesso em: 1.set.2010.

. 1999. Instituições eleitorais e desempenho do presidencialismo no Brasil. Dados, Rio de Janeiro, v. 42, n. 1, p. 111-138. Disponível em: http://www.scielo.br/scielo.php?pid= S0011-52581999000100006\&script= sci_arttext. Acesso em: 1.set.2010.

2002. Partidos e comissões no presidencialismo de coalizão. Dados, Rio de Janeiro, v. 45. n. 2, p. 237-264. Disponível em: http:// www.scielo.br/scielo.php?script= sci_arttext\&pid=S0011-52582002000200003. Acesso em: 1.set.2010.

2006. Em defesa do presidencialismo de coalizão. In: SOARES, G. \& RENNÓ, L. (orgs.). Reforma Política: lições da história recente. Rio de Janeiro: Fundação Getúlio Vargas.

2007. A República de 46: separação de poderes e política alocativa. In: MELO, C. \& ALCÂNTARA, M. (orgs.). A democracia brasileira: balanços e perspectivas para o século 21. Belo Horizonte: UFMG.

SANTOS, F. \& ALMEIDA, A. 2005. Teoria informacional e a seleção de relatores na Câmara dos Deputados. Dados, Rio de Janeiro, v. 48, n. 4, p. 693-735. Disponível em: http:// www.scielo.br/scielo.php?pid=S001152582005000400001\&script=sci_arttext. Acesso em: 1.set.2010.

SHEPSLE, K. 1989. Studying Institutions: Some Lessons from the Rational Choice Approach. Journal of Theoretical Politics, Los Angeles, v.1, p. 131-147.

SINCLAIR, B. 1995. House Special Rules and the Institutional Design Controversy. In: SHEPSLE, K. \& WEINGAST, B. (ed.) Positive Theories of Congressional Institutions. Ann Arbor: University of Michigan.

STROM, K. 1990. Minority Government and Majority Rule. Cambridge: Cambridge University. 


\section{OUTRAS FONTES}

AGÊNCIA CÂMARA DE NOTÍCIAS. 2007. Disponível em: http://www2.camara.gov.br/ internet/homeagencia. Acesso em: 1.dez.

2008. Disponível em: http://www2.camara. gov.br/internet/homeagencia . Acesso em: 1.mar.

BRASIL. 1934. Constituição da República dos Estados Unidos do Brasil. Disponível em: http://www2.camara.gov.br/legislacao. Acesso em: 1.dez.2007.

1937. Constituição da República dos Estados Unidos do Brasil. Disponível em: http:// www2.camara.gov.br/legislacao. Acesso em: 1.dez.2007.

1946. Constituição dos Estados Unidos do Brasil. Disponível em: http:// www2.camara.gov.br/legislacao. Acesso em: 1.dez.2007.

1967. Constituição do Brasil. Disponível em: http://www2.camara.gov.br/legislacao. Acesso em: 1.dez.2007.

1969. Emenda Constitucional n. 1. Disponível em: http://www2.camara.gov.br/ legislacao . Acesso em: 1.dez.2007.

1988. Constituição da República Federativa do Brasil. Disponível em: http:// www2.camara.gov.br/legislacao. Acesso em: 1.dez.2007.

BRASIL. Câmara dos Deputados. 1989. Resolução da Câmara dos Deputados n. 17. Aprova o Regimento Interno da Câmara dos Deputados. Disponível em: http:// www2.camara.gov.br/legislacao. Acesso em: 1.dez.2007.

BRASIL. Congresso Nacional. 1995. Resolução n. 2. Dispõe sobre a Comissão Mista Permanente a que se refere o $\S 1^{\circ}$ do art. 166 da Constituição Federal, e sobre a tramitação das matérias a que se refere o mesmo artigo. Disponível em: http://www2.camara.gov.br/ legislacao. Acesso em: 1.dez.2007.

2000. Resolução n. 2. Dispõe sobre a participação das bancadas minoritárias na composição das comissões mistas. Disponível em: http://www2.camara.gov.br/legislacao. Acesso em: 1.dez.2007.
2006. Resolução n. 1. Dispõe sobre a Comissão Mista Permanente a que se refere o $\S 1^{\circ}$ do art. 166 da Constituição, bem como a tramitação das matérias a que se refere o mesmo artigo. Disponível em: http:// www2.camara.gov.br/legislacao. Acesso em: 1.dez.2007.

BRASIL. Senado Federal. 1970. Resolução n. 93. Regimento Interno do Senado Federal. Disponível em: http://www2.camara.gov.br/ legislacao. Acesso em: 1.dez.2007.

1993a. Resolução n. 17. Dispõe sobre a Corregedoria Parlamentar. Disponível em: http://www2.camara.gov.br/legislacao. Acesso em: 1.dez.2007.

1993b. Resolução n. 20. Institui o Código de Ética e Decoro Parlamentar. Disponível em: http://www2.camara.gov.br/legislacao. Acesso em: 1.dez.2007.

1995. Resolução n. 40. Institui a Procuradoria Parlamentar e dá outras providências. Disponível em: http://www2.camara.gov.br/ legislacao. Acesso em: 1.dez.2007.

2005. Resolução n. 1. Cria no Senado Federal a Comissão de Agricultura e Reforma Agrária, altera a denominação e atribuições de comissões permanentes e dá outras providências. Disponível em: http:// www2.camara.gov.br/legislacao. Acesso em: 1.dez.2007.

2006. Resolução n. 35. Altera o Regimento Interno do Senado Federal, para disciplinar a representação partidária nos colegiados, o Acesso em à palavra, a tramitação em conjunto de proposições legislativas, a retirada de proposições e as decisões tomadas mediante acordo de lideranças. Disponível em: http:// www2.camara.gov.br/legislacao. Acesso em: 1.dez.2007.

.2007a. Resolução n. 01, de 2007. Cria no Senado Federal a Comissão de Ciência, Tecnologia, Inovação, Comunicação e Informática - CCT. Disponível em: http:// www2.camara.gov.br/legislacao. Acesso em: 1.dez. 
.2007b. Resolução n. 03, de 2007. Altera o $\S 1^{\circ}$ do art. 77 do Regimento Interno do Senado Federal, para permitir que os membros da Comissão Diretora, à exceção do Presidente, possam integrar outras comissões permanentes. Disponível em: http:// www2.camara.gov.br/ legislacao. Acesso em: 1.dez.
RESOLUÇÃO DO TSE SOBRE FIDELIDADE PARTIDÁRIA É CONFIRMADA PELO SUPREMO. 2008. Agência de Notícias do Tribunal Superior Eleitoral, Brasília, 12.nov. Disponível em: http://www.tse.gov.br/ sadAdmAgencia/noticiaSearch.do? acao $=$ get\&id=1131474. Acesso em: 13.nov. 


\section{DELEGATION OF PARTY LEADERS IN THE BRAZILIAN HOUSE OF REPRESENTATIVES AND THE FEDERAL SENATE}

\section{Geralda Luiza de Miranda}

In this article, we compare the prerogatives of leaders who coordinate legislative processes and distribute positions in the House and the Senate. The comparison is carried out through analysis of the regiments and resolutions that have regulated the dynamic of the two Houses since 1989. The Senate Daily Reports, reports put together by the House News Agency, and studies that deal with Brazilian legislative dynamics illustrate our analysis and provide an empirical base for a variety of inferences. Analysis reveals the central role of leadership in coordinating the legal process and in the distribution of positions, especially within the House of Representatives, that is, the importance these actors have in allowing members of parliament to go beyond the practical imperatives of collective action and maximize their preferences. It also reveals important institutional changes that have positively influenced the content of what has been delegated to leadership. To the extent that leadership has been strengthened and, consequently, political parties as well, these changes point to the strengthening of Legislative power vis-à-vis the Executive.

KEYWORDS: political parties; legislative delegation; internal regiment; House of Representatives; Federal Senate. 


\section{LA DELEGATION AUX LEADERS DES PARTIS DANS LA CHAMBRE DES DEPUTES ET DANS LE SENAT FEDERAL BRÉSILIENS}

\section{Geralda Luiza de Miranda}

Dans cet article, sont comparées les prérogatives des leaders pour coordonner le processus législatif et pour distribuer des positions dans la Chambre et dans le Sénat. La comparaison est faite à partir de l'analyse des régiments et résolutions qui régulent la dynamique des deux chambres après 1989. "Les Journaux du Sénat", les reportages diffusés par "l'Agence Chambre de Nouvelles", et les études qui s'occupent de la dynamique législative brésilienne, illustrent l'analyse et fournissent la base empirique de plusieurs interférences. L'analyse montre la centralité des leaderships dans la coordination du processus législatif et dans la distribution des positions, spécialement dans la Chambre des Députés ; c'est-à-dire, l'importance de ces acteurs pour que les parlementaires puissent surmonter les impératifs pratiques de l'action collective et maximiser leurs préférences. Elle montre aussi des changements institutionnels importants qui influencent positivement le contenu de la délégation aux leaders. Dans la mesure où elles renforcent les leaderships et, donc, les partis politiques, ces changements pointent au renforcement du pouvoir Législatif vis-à-vis le pouvoir Exécutif.

MOTS-CLES : partis politiques ; délégation législative ; régiment interne ; Chambre des Députés ; Sénat Fédéral. 